\title{
Conocimiento, traza e ingenio en la arquitectura valenciana del siglo $\mathrm{XV}$
}

\author{
Amadeo Serra Desfilis \\ Departamento de Historia del Arte \\ Universitat de València \\ amadeo.serra@uv.es
}

\begin{abstract}
RESUMEN
La historiografía de la arquitectura gótica en la Corona de Aragón se ha dedicado en las últimas décadas principalmente a las monografías de edificios, la investigación documental y al cambio técnico de la construcción en piedra. Por otra parte, los historiadores de la tecnología han prestado atención especial a la cuestión de la innovación y a su difusión en la Baja Edad Media, considerando las técnicas de construcción como un campo especial de investigación. Este trabajo estudia la transmisión del conocimiento técnico en los oficios de la construcción para explicar los cambios arquitectónicos en un entorno aventajado de innovación como era el reino de Valencia en los siglos XIV y XV, en particular a partir de 1430. Teniendo en cuenta las investigaciones precedentes y algunos casos de estudio, bien documentados en las fuentes escritas, este artículo aborda cuestiones como la movilidad de los maestros de obras, la transferencia de modelos y exempla, el dibujo arquitectónico y la formación técnica en los oficios de la construcción.
\end{abstract}

Palabras clave: arquitectura valenciana, siglo $\mathrm{XV}$, transmisión del conocimiento técnico, movilidad de maestros, formación técnica.

\begin{abstract}
In the last decades historiography of gothic architecture in the Crown of Aragon has focused on buildings monographs, documentary research and technical change in stone building. On the other hand, historians of technology have given special attention to the issue of innovation and its diffusion in the late Middle Ages, considering building techniques as a particular field of research. This essay studies transmission of technical knowledge in building trades in order to explain architectural changes in an outstanding environment of innovation such as the kingdom of Valencia in the $14^{\text {th }}$ and $15^{\text {th }}$ centuries, especially from 1430 onwards. Having account of previous research and some cases of study, well documented by abundant written sources, this article addresses questions as mobility of master builders, transfer of models and exempla, architectural design and the technical education of building crafts.
\end{abstract}

Keywords: valencian architecture, $15^{\text {th }}$ century, transmission of technical knowledge, mobility of master builders, technical education.

La arquitectura del siglo XV en la Corona de Aragón fue agitada por vientos de cambio, como en el resto de Europa. Las novedades constructivas y en el repertorio ornamental asomaron a finales del siglo XIV y prosiguieron a lo largo de la centuria siguiente en un panorama dominado por la movilidad de los maestros, la transferencia de modelos y la pujanza de la arquitectura como elemento de prestigio y distinción entre los intereses de los promotores más poderosos. Las obras que condensaron las innovaciones de todo orden y las trayectorias de los protagonistas han sido ampliamente indagadas por la historiografía más reciente basándose en las 
fuentes documentales y en el estudio técnico de las estructuras conservadas, aunque el particularismo y la fragmentación de muchos trabajos requieren el encaje en un panorama más general, peninsular, mediterráneo e internacional.

Este trabajo se concentra en el problema de la transmisión del conocimiento en los oficios de la construcción como una vía de explicación de los cambios arquitectónicos de la Corona de Aragón y en particular del ámbito valenciano durante el siglo XV, dado el cúmulo en este territorio de procesos de innovación en la segunda mitad de la centuria. Para ello contamos con algunos precedentes ${ }^{1}$ y buen número de casos de estudio que intentaremos integrar en una visión de conjunto, comparativa si es posible con otros ejemplos europeos, pues la arquitectura tardogótica de la Corona de Aragón estaba conectada con la red de intercambios y transferencias que se extendía por todo el continente y los archipiélagos vecinos.

\section{Conocimiento técnico e innovación}

Dos vías complementarias para aproximarse al problema provienen, por una parte, de la historia de la técnica y la difusión de innovaciones en época medieval y la primera Edad Moderna; por otra, del carácter específico del conocimiento técnico en el mundo de la construcción, que ha interesado más a la historia de la arquitectura. Para la historia de la tecnología, la circulación de la innovación no consiste en replicar los modelos, pues éstos deben aclimatarse al entorno particular de cada país, a las necesidades de la población y su éxito depende, en última instancia, de la capacidad de adaptación a circunstancias diversas de aquellas en las que surgieron las novedades. Como saberes aplicados a la solución de problemas, las técnicas no se basan necesariamente en principios universales y pertenecen al mundo de la singularidad, la contingencia y la heterogeneidad. Así, la construcción de un puente es un problema planteado a partir de numerosas variables que puede encontrar soluciones variadas y alternativas, que dependen a su vez de los medios técnicos, humanos y las circunstancias ambientales del lugar.

Por otra parte, la transmisión del conocimiento depende de recursos materiales y culturales, más allá de la técnica en sentido estricto. Entre estos factores cuenta la formación de los individuos y su movilidad, en especial cuando se trata de un saber no codificado. Aunque existan tratados técnicos, no bastan por sí solos como vectores de la innovación, que está en manos sobre todo de las personas competentes y de los productos. Pero las transferencias están también condicionadas por el papel de los intermediarios, los consumidores, las instituciones y los centros de poder. La consecuencia principal de esta interacción es que los mediadores interpretan y adaptan las novedades a las necesidades de una comunidad o un territorio,

1 F. ESPAÑOL BERTRAN, "La transmisión del conocimiento artístico en la Corona de Aragón (siglos XIV y XV)", Cuadernos del CEMYR: Saber y conocimiento en la Edad Media, 5 (1997), pp. 77-113. 
las cuales nutren y constriñen a la vez la circulación de técnicas innovadoras ${ }^{2}$. En el ámbito de la Corona de Aragón las obras hidráulicas son un buen ejemplo de cómo se filtran y promueven ciertas capacidades, se acumula el conocimiento en manos de una élite de expertos y se aplican los saberes para atender las necesidades humanas sobre el territorio. Aparte de la transferencia técnica que se produjo entre musulmanes y cristianos en el este peninsular ${ }^{3}$, es notorio cómo se requieren los servicios de expertos en hidráulica en diferentes lugares del territorio para resolver problemas de abastecimiento, defensa contra las avenidas, saneamiento de aguas residuales, canalización y riegos. En tierras valencianas los niveladores (livelladors) eran técnicos especializados en estudiar, trazar y construir acequias y todo tipo de canalizaciones; competentes como agrimensores y constructores, se reclutaban preferentemente entre los maestros de obras ${ }^{4}$. El aprecio de un conocimiento en grado de maestría en este campo, propiciaba la movilidad de los maestros, la consulta de varias opiniones expertas y algo parecido a un concurso de ideas para afrontar grandes proyectos hidráulicos.

Un otoño seco en 1374 indujo a plantear a los regidores valencianos un trasvase de aguas desde el Júcar, cerca de Tous, hasta el Turia a la altura de Manises, para poner en regadío nuevas partidas de huerta y suplir agua a la ciudad en periodos de sequía ${ }^{5}$. Aunque respaldaban la propuesta también "algunas personas expertas en ello", el 3 de octubre del año siguiente el Consejo municipal encomendó a "personas expertas en el arte de geometría" y otras, sabias y discretas, que estudiasen las posibilidades técnicas del audaz proyecto, "puesto que la ciudad tenía algunos buenos maestros en el arte de la geometría y el nivel", pero no se descartaba consultar a otros peritos ${ }^{6}$. Se acudió por tanto a maestros de Barcelona y Manresa y entre los locales se contaron Bernat Boix, y Bernat Tosquella, quienes acudieron a "nivelar el lugar y estimar el coste de la obra" en febrero de $1376^{7}$. Boix acababa de ser nombrado maestro mayor de la obra de los muros de la ciudad y había recibido el

2 L. HILAIRE-PÉREZ y C. VERNA, "La circulation des savoirs techniques du Moyen Âge à l'époque moderne. Nouvelles approches et enjeux méthodologiques", Tracés, 16 (2009), pp. 25-61.

3 T.F. GLICK, Irrigation and hydraulic technology: medieval Spain and its legacy, Aldershot, 1996; y Paisajes de conquista: cambio cultural y geográfico en la España medieval, Valencia, 2007, entre otros autores, ha insistido en estas transferencias.

4 T.F. GLICK, Regadio y sociedad en la Valencia medieval, Valencia, 1988, pp. 363-367. Un panorama de la actividad de los maestros de obras valencianos en la ingeniería hidráulica se debe a A. ZARAGOZÁ CATALÁN, Arquitectura gótica valenciana, Valencia, 2000, pp. 204-206.

Archivo Municipal de Valencia (en adelante AMV), Manual de Consells, A-16, f. 225r, citado por M.M. CÁRCEL ORTÍ y J. TRENCHS ODENA, "El Consell de Valencia: disposiciones urbanísticas (siglo XIV), La ciudad hispánica de los siglos XI al XVI, vol. II, Madrid, 1985, p. 1516.

6 AMV, Manual de Consells, A-17, f. 20r-v, 3-X-1375, citado por T.F. GLICK, op. cit., 1988, pp. 151152.

AMV, Manual de Consells, A-17, ff. 38v-39v, y f. 40v. Bernat Boix y Bernat Tosquella comparecen en la segunda sesión mencionada. A. SERRA DESFILIS, "Caminos, acequias y puentes. Las actividades de los maestros de obras en la ciudad y el territorio de Valencia (siglos XIV y XV)", F. TABERNER (ed.), Historia de la ciudad II: territorio, sociedad y patrimonio, Valencia, 2002, pp. 112-113. 
elogio de ser "maestro de obras y edificios, muy capaz y competente en aquel arte", poco después de asumir el cargo de maestro mayor de la obra del Real de Valencia con los derechos y salarios que este título comportaba ${ }^{8}$. Bernat Tosquella, en cambio, estaba asociado al mundo de la carpintería y la talla en madera y pertenecía a una familia de escultores que trabajó en el coro de la Catedral de Valencia, en la Cartuja de Valldecrist (Altura), en el coro de la Iglesia del Carmen y al servicio de la cofradía de San Jaime de Valencia ${ }^{9}$.

La obra de la Fuente del Ángel en Tortosa es representativa de esta clase de proyectos. Los procuradores de la ciudad querían disponer de agua cerca del convento de franciscanos "para utilidad de la cosa pública de esta ciudad y así mismo para decorar y ennoblecerla" con el propósito de construir una fuente monumental en el centro urbano, teniendo como modelo plausible las fuentes de Barcelona. Para llevar a cabo la obra se asesoraron del maestro Bertomeu Casanova, setabense, aprovechando que se encontraba en Sant Mateu (1442), pero la lápida y la inscripción conmemorativa, datada en 1440, recuerda el nombre del maestro Guillem Çaera y quizá fuera él el enviado a Barcelona con la misión de "informarse de los maestros de las fuentes de Barcelona"10.

Del impulso que dieron a la carrera de los maestros las obras hidráulicas dan cuenta las trayectorias de personajes como Arnau Bargués en la Cataluña de $1400^{11}$ u Onofrio di Giordano, con su actividad ingenieril entre Roma, Nápoles y Dalmacia ${ }^{12}$. Bargués declaró ante el municipio barcelonés en 1402 haber construido o

8 A. RUBIÓ I LLUCH, Documents per a la història de la cultura catalana mig-eval, vol. II, Barcelona, 1921, p. 180, documento CXCIII. Bernat Boix seguía ocupando el cargo en 1388, véase H. BORJA, "Animals exòtics al Palau Reial de València”, Boletín de la Sociedad Castellonense de Cultura, LXXVIII (2002), p. 76. A. SERRA DESFILIS, "El fasto del palacio inacabado. La Casa de la Ciudad de Valencia en los siglos XIV y XV", F. TABERNER (ed.), Historia de la ciudad III: Arquitectura y transformación urbana en la ciudad de Valencia, Valencia, 2004, pp. 73-99, acerca de su papel como maestro de las obras muros y fosos y de la Casa de la Ciudad de Valencia.

9 Bernat Tosquella estuvo al frente de la sillería del coro de la Seo valentina desde 1394 con su hijo Francesc. Acerca de la familia Tosquella en Valencia véase M. MIQUEL JUAN, "El coro de la catedral de Valencia (1384-1395). La introducción de nuevos elementos decorativos del gótico internacional en Valencia”, A. SERRA DESFILIS (ed.), Arquitectura en construcción en Europa en época medieval y moderna, Valencia, 2010a, pp. 349-376, en especial, pp. 368-372. La actividad de los Tosquella en el coro de la capilla de San Martín de la Cartuja de Valldecrist ha sido estudiada por C. LLANES I DOMINGO, "Els Tosquella, fusters i mestres del cor de la capella de sant Martí a Valldecrist (c. 1390)", Cartuja de Valldecrist (14052005). VI Centenario del inicio de la Obra Mayor, Segorbe, 2008, pp. 223-246.

10 "per utilitat de la cosa pública de aquesta ciutat, e axí matex per decorar e ennoblir aquella"; "informar-se del maestres de les fonts de Barchinona”, J. VIDAL FRANQUET, Les obres de la ciutat. L'activitat constructiva de la Universitat de Tortosa a la baixa Edat Mitjana, Barcelona, 2008, pp. 106-112.

11 M.R. TERÉS I TOMÀS, “Arnau Bargués, arquitecto de la ciudad de Barcelona. Nuevas aportaciones documentales”, Boletín del Museo e Instituto Camón Aznar, 9 (1982), pp. 72-86; y “Arnau Bargués (c. 13741413)", E. GAROFALO y M.R. NOBILE (eds.), Gli ultimi independenti. Architetti del gotico nel Mediterraneo tra XV e XVI secolo, Palermo, 2007, pp. 23-43.

12 A. GHISETTI GIAVARINA, "Onofrio di Giordano", E. GAROFALO y M.R. NOBILE (eds.), op. cit., pp. 45-57. 
reformado tres fuentes públicas, el canal de aguas conocido como Rech Reyal, y haber intervenido en el cauce del río Besós, entre otras obras. Al terminar las obras de encauzamiento del Besós para evitar futuras inundaciones recibió en 1403 una gratificación extraordinaria junto a Bernat Desplà, "poseedores de experiencia y conocimiento para nivelar las aguas"13. Se reconocía, pues, una capacidad contrastada para atajar los problemas de canalización de las aguas y la defensa frente a las avenidas y se valoraba su utilidad para el bien común, que redundaba en la promoción de los artífices más competentes.

\section{El conocimiento aplicado en la arquitectura}

La formación de los constructores ha captado el interés de la historiografía de la arquitectura, pero no se ha alcanzado todavía un consenso estable sobre los diversos aspectos del problema. Si el valor de la experiencia, el carácter aplicado de los conocimientos y la importancia del dibujo arquitectónico son generalmente admitidos, en cambio los vehículos de transmisión del saber técnico, el contenido de la enseñanza en el seno de los talleres y la hipotética relación con el pensamiento teórico de aquellos siglos siguen suscitando controversia ${ }^{14}$. Aparte del célebre cuaderno de Villard de Honnecourt ${ }^{15}$, la transmisión oral del conocimiento técnico y los instrumentos para su aplicación, las eventuales relaciones entre la geometría constructiva (geometría fabrorum), la agrimensura de tradición romana y el legado de Euclides, así como el cálculo y el valor atribuidos a la medida y la proporción de las construcciones son algunas de las cuestiones que permanecen abiertas, aunque el paso de la traza a la construcción sigue siendo un terreno más firme y llano para la investigación ${ }^{16}$.

\footnotetext{
13 “havents experiencia e noticia d'allivellar aygues", M.R. TERÉS I TOMÁS, op. cit., 1982, pp. 72-86; y op. cit., 2007, p. 33.

14 M.T. ZENNER, “Architectural Layout: Design, Structure, and Construcion in Northern Europe”, C. RUDOLPH (ed.), A Companion to Medieval Art, Oxford, 2006, pp. 534-541 ofrece una revisión del tema en la Europa septentrional.

15 A. ERLANDE-BRANDENBURG, J. GIMPEL, R. PERNOUD y R. BECHMANN, Villard de Honnecourt: cuaderno, siglo XIII, Madrid, 1991; R. BECHMANN, Villard de Honnecourt. La pensée technique au XIIIe siècle et sa communication, París, 1991; C.F. BARNES, The Portfolio of Villard de Honnecourt, Farnham, 2009.

16 L.R. SHELBY, “The Education of Medieval English Master Masons”, Medieval Studies, 32 (1970), pp. 1-26 y "The geometrical knowledge of medieval master masons", Speculum, 47 (1972), pp. 395-421, siguen siendo la referencia clásica, pero han sido sometidos a críticas recientes por visiones que reconsideran la relación entre la geometría de los constructores y la tradición clásica de Euclides, como M.T. ZENNER, "Imaging a Building: Latin Euclid and Practical Geometry", J.J. CONTRENI (ed.), Word, Image, Number: Communication in the Middle Ages, Florencia, 2002, pp. 219-246; y M.T. ZENNER, op. cit., 2006, pp. 539541. Sobre el conocimiento matemático de los constructores véase también los trabajos de K. HECHT, Mass und Zahl in der gotischen Baukunst, Hildesheim, 1979, quien pone en cuestión muchas reconstrucciones de trazados geométricos ideales en la arquitectura gótica, y M. T. SARRADE, Les connaissances mathématiques des constructeurs du Moyen Age, París, 1996.
} 


\section{Aprender a construir}

El conocimiento aplicado de la arquitectura reunía en los últimos siglos de la Edad Media unas características propias ${ }^{17}$. El aprendizaje del oficio hasta alcanzar la categoría de experto era un proceso largo, que podía rebasar los límites de la juventud para una época en que la experiencia de vida era mucho más reducida. Además las labores implicaban a menudo un notable esfuerzo físico y los más jóvenes no podían ofrecer el mismo rendimiento que un adulto. Así no es extraño que hombres maduros trabajen como ayudantes de maestros expertos o que lleguen a integrarse como aprendices en su equipo de canteros y que los años de formación impliquen estancias lejos del lugar de origen. En este aspecto, los contratos de aprendizaje, aunque relativamente escasos, son una fuente preciosa de información si bien dejan fuera otras formas de enseñanza no reglada de los oficios artísticos. Su estudio revela una gran variedad de situaciones que pueden disimular sistemas de subcontratación o incorporación temporal de personal ya formado a un grupo de trabajo. En catalán, afermar es un verbo que indica también un convenio mutuo entre dos personas y no necesariamente entraña un proceso de aprendizaje. Son numerosos los contratos en los que el aprendiz era ya mayor de edad y el período de prácticas junto al maestro es variable, por lo que quizá conviniera distinguir entre genuinos contratos de aprendizaje y contratos de trabajo subalterno ${ }^{18}$. No obstante, la idea del aprendizaje a lo largo de la vida no era del todo ajena a la mentalidad medieval, si atendemos a algunos ejemplos como el del carpintero Juan de Raymaç, mayor de edad y natural de Monzón

17 L. HILAIRE-PÉREZ y C. VERNA, op. cit., 2009, pp. 38-39.

18 En general, véase P. BUCHBINDER, Maestros y aprendices: estudio de una relación social de producción (España, siglos XV-XVII), Buenos Aires, 1991; J. BAUCELLS I REIG, "L'estament dels aprenents dels segles XIII i XIV segons els contractes notarials de Barcelona”, Estudios históricos y documentos de los archivos de protocolos, V (1978), pp. 85-142; J. DOMENGE I MESQUIDA, "Entorn als oficis artístics de Mallorca. Una aproximació als treballs i ocupacions dels artistes medievals (segles XIV-XVI)", M. BARCELÓ I CRESPÍ (ed.), La manufactura urbana i els menestrals (segles XIII-XVI), IX Jornades d'Estudis Històrics Locals, Palma de Mallorca, 1991, pp. 381-398, trata también sobre el sistema de aprendizaje; M. CARBONELL I BUADES, "Marc Safont (ca. 1386-1458) en l'arquitectura barcelonina del segle XV. Documents per a un esbós biogràfic”, Estudis històrics i documents del arxius de protocols, XXI (2003), pp. 181-225, en particular, p. 204, registra cinco aprendices vinculados formalmente a Marc Safont y compara las condiciones de sus contratos. Sobre la situación valenciana, véanse los trabajos de J.M. CRUSELLES GÓMEZ, Escuela y sociedad en la Valencia bajomedieval, Valencia, 1997, en especial, pp. 139-205, donde estudia la formación de los estratos intermedios y la alfabetización; más específico para el mundo artesanal, G. NAVARRO ESPINACH, "Las etapas de la vida en las familias artesanas de Aragón y Valencia durante el siglo XV”, Aragón en la Edad Media, 18 (2004) pp. 203-244; J. APARICI MARTÍ, "El trabajo de los jóvenes en la Edad Media: Contratos de 'Afermament' de Vila-real", Millars. Espai $i$ història, 18 (1995), pp. 97-114; y J. APARICI MARTÍ y G. NAVARRO ESPINACH, “Considerada encara la pocha edat e ignocència. Los primeros años de la vida para los niños del siglo XV”, Millars. Espai $i$ història, 33 (2010), pp. 55-74. Un panorama de conjunto del aprendizaje artístico y arquitectónico en la Corona de Aragón durante los siglos XIV y XV, todavía inédito, se debe a E. MONTERO TORTAJADA, L'aprenentatge dels oficis artístics a la Corona d'Aragó (1370-1450), Memòria final de la Borsa d'estudis Països Catalans, 2007. 
(Huesca), al colocarse a sí mismo por dos años con el carpintero valenciano Bernat Tàrrega, con un sueldo anual ${ }^{19}$.

Pere Manrique, vecino de Manresa, se vinculó con el maestro de obras valenciano Antoni Prats por un año aportando muchas de las herramientas propias de su oficio, mientras que Diego de Ayala se incorporó con 15 años de edad como aprendiz al taller de Asensi de la Fos por un período de cinco años. Es patente que se trataba de casos muy diferentes, pues el primero parece una breve estancia de formación o perfeccionamiento, para un joven que ya conoce al menos los rudimentos de la profesión y procede de otro lugar, mientras que el segundo casa mejor con la idea convencional del aprendizaje: un vínculo largo para enseñar a una persona muy joven, que tardará en dominar el oficio y servirá a su maestro mientras tanto. El vínculo de Juan de León, cantero proveniente de Castilla, con Francesc Baldomar por un año, cuando ya había alcanzado la mayoría de edad, tiende a confirmar esta interpretación, si se compara con el de Pere Riera, hijo de otro cantero, con el valenciano Julià Martínez, que debía instruirle durante tres años y medio y llegó con algunas herramientas propias de su oficio ${ }^{20}$. El contrato de Pere Gironés, ciudadano de Gerona, con el maestro valenciano Antoni Dalmau se suscribió por dos años y medio, comprometiéndose el segundo a enseñarle el oficio, alojarle y pagar una soldada de 20 florines reales de Valencia en concepto de salario ${ }^{21}$. En ocasiones, se preveía que al final del período estipulado el joven recibiera indumentaria y un juego de herramientas para empezar su carrera profesional, lo que parece un indicio claro de un auténtico proceso de aprendizaje. Así Pere Sánxez, de 15 años, debía ser instruido por el maestro de obras (obrer de vila) Miquel Roda, recibiendo manutención, ropa y calzado durante cuatro años así como ropa y las herramientas para ejercer su oficio al cabo de ese tiempo ${ }^{22}$.

También son llamativos los hijos de constructores que se ligan mediante un contrato de aprendizaje con un maestro distinto, a veces residente en otra ciudad. Por el mismo instrumento que ratificó la vinculación de Pere Gironés al taller de

19 Citado por G. NAVARRO ESPINACH, op. cit., 2004, p. 228.

${ }^{20}$ El contrato de aprendizaje de Pere Riera fue dado a conocer por J. SANCHIS SIVERA, "Maestros de obras y lapicidas valencianos en la Edad Media", Archivo de Arte Valenciano, XI (1925), pp. 23-52, p. 38. A. ZARAGOZÁ y M. GÓMEZ-FERRER, Pere Compte, arquitecto, Valencia, 2007, p. 217, para los demás documentos citados.

${ }^{21}$ M. GÓMEZ-FERRER LOZANO, "La cantería valenciana en la primera mitad del XV: El maestro Antoni Dalmau y sus vinculaciones con el área mediterránea", Anuario del Departamento de Historia y Teoría del Arte, IX-X (1997-1998), pp. 91-105, con la transcripción en pp. 102-103; comenta el contrato por dos años de dos aprendices de los canteros Pere de Girona y Martí Pi; M. CARBONELL I BUADES, "De Marc Safont a Antoni Carbonell: la pervivencia de la arquitectura gótica en Cataluña”, Artigrama, 23 (2008), pp. 97-148, traza la semblanza de Andreu Pi en pp. 120-125; véase también, A. ZARAGOZÁ y M. GÓMEZFERRER, op. cit., 2007, p. 317.

22 Archivo de Protocolos del Patriarca de Valencia, Joan Çaposa, nº 24713, 16 de agosto de 1423. Entre los testigos figura el conocido maestro Martí Llobet. Noticia facilitada por la investigadora Encarna Montero Tortajada, a quien agradezco su gentileza. 
Antoni Dalmau se incorporó Martí, hijo del maestro de obras barcelonés, Andreu Pi, por dos años. Joan Llobet el Viejo, maestro de la Catedral de Valencia, formó al hijo del cantero Vicent Cubells, pero su propio vástago, Martí Llobet, completaría su formación en la Catedral de Barcelona, a las órdenes de Bertomeu Gual ${ }^{23}$. Es probable que tras estos movimientos hubiera el deseo de acceder a una formación complementaria de la que se había recibido en el seno del taller familiar: Joan Llobet trabajó principalmente como escultor y su hijo Martí podía ampliar su preparación en otro taller catedralicio activo como el barcelonés, impregnado de novedades en aquellos años, junto a un maestro arquitecto. La formación de Antoni Dalmau junto al escultor Pere Joan es muy plausible y cabe entenderla como una simbiosis oportuna entre el oficio del cantero y el del escultor innovador empeñado en obras de gran envergadura. No sorprende que las primeras noticias sobre Antoni Dalmau en Valencia, tras su paso por el retablo mayor de la Seo de Zaragoza, lo sitúen en el campo de la escultura figurativa y reseñen su destreza para la talla del alabastro, material de uso esporádico en la Valencia de entonces, pero con el que estaba familiarizado Pere $\mathrm{Joan}^{24}$. Se ha sugerido que los años de aprendizaje del hijo de un maestro cantero como Bertomeu Durà junto al orfebre Bernat Santalínea pudieron servir para formarse en el uso más sofisticado del dibujo para la traza ${ }^{25}$. Sin embargo, otros cambiaban por completo de oficio y campo profesional: Domenico Mucari, hijo del obrero de villa Barnabà, de Messina, se colocó con 18 años como aprendiz de un adobador de cueros valenciano en $1466^{26}$. En todo caso, no es fácil saber qué valoraron los padres o tutores en los maestros elegidos para formar a los jóvenes, aparte de los intereses familiares o de promoción social, ni mucho menos qué habilidades en particular querían adquirir los aprendices o inculcarles sus tutores.

Por otra parte, cabe suponer que muchos aprendices no cumplían con estas formalidades ante el notario y que otros no llegaban a establecerse por cuenta propia al terminar su período de formación, como sucedía en muchos oficios. Los apellidos más repetidos en la documentación valenciana de esta época, como los Llobet, reflejan la continuidad en la profesión de varias generaciones de una misma familia y, por tanto de un obrador, con las herramientas, conocimientos y relaciones sociales que lo sustentaban, aunque no sepamos nada de la duración del aprendizaje ni del proceso de formación. De los Amorós conocemos a la generación de los hermanos

${ }^{23}$ La noticia del contrato de aprendizaje de Antoni Cubells, hijo del cantero Vicent Cubells, en X. COMPANY, J. ALIAGA, L. TOLOSA y M. FRAMIS, Documents de la pintura valenciana medieval i moderna, I (1238-1400), Valencia, 2005, p. 343; véase también M. MIQUEL JUAN, "Martí Lobet en la catedral de Valencia (1417-1439)", F. TABERNER (ed.), Historia de la ciudad VI. Proyecto y complejidad, Valencia, 2010b, pp. 104-106.

24 M. GÓMEZ-FERRER LOZANO, op. cit., 1997-1998, pp. 91-105.

25 A. ZARAGOZÁ CATALÁN, "Sueños de arquitecturas en el episodio gótico valenciano", Penyagolosa, IV época, 1 (1999), pp. 9-18, en especial, p. 14.

${ }^{26}$ Citado por G. NAVARRO ESPINACH, op. cit., 2004, p. 228. 
Pere y Lluís Amorós el Viejo, así como a los hijos de éste: Lluís el Joven, Joan y Gabriel, y su yerno, Miquel Peris, también albañil, sin que nos conste si tenían algún parentesco con los carpinteros Joan y Juli Amorós, como parece probable a la vista del trasvase corriente entre ambos oficios en el ámbito valenciano ${ }^{27}$. En ocasiones se advierte cómo un joven crece al lado de un maestro famoso o bien comparte con él unos años que se antojan decisivos en su formación técnica. De lo primero es un ejemplo la actividad de Pere Compte al lado de Francesc Baldomar en obras como la capilla real del Convento de Santo Domingo de Valencia o la catedral de la misma ciudad; de lo segundo, el paso de un joven Joanet del Poyo por la fábrica del Portal de los Serranos en Valencia, dirigida entonces por el notable Pere Balaguer ${ }^{28}$.

El saber constructivo requiere una constante adaptación a las condiciones particulares del sitio, los materiales, la fuerza de trabajo o los fondos disponibles, y en la práctica muchas obras consisten en continuar, reparar o reformar proyectos ya emprendidos. Por ello, la experiencia es un grado importantísimo pero no debe ser la única fuente de conocimiento, ya que conviene examinar las condiciones del lugar, los elementos preexistentes y la viabilidad del programa de construcción, todo lo cual se traduce en una exigencia de versatilidad y dotes de innovación en un marco concreto de operaciones. El ingenio consistía en la capacidad de resolver problemas técnicos combinando habilidad manual en el manejo de materiales y herramientas y sutileza intelectual, a tenor del testimonio de las fuentes, que reflejan por otra parte el punto de vista de los promotores ${ }^{29}$. En este contexto, las consultas a diversos maestros contaron con el aval de la trayectoria y del cargo que ocupaban cada uno de ellos, pero exigieron también un desplazamiento al teatro de operaciones, la inspección detenida de la obra y respuestas específicas a las preguntas que planteaban los clientes y mentores, por más que en ellas los implicados adujeran principios generales y nociones basadas en su experiencia. Los maestros consultados en Gerona en 1386 y 1416, o en Milán, debían sacar de dudas a los promotores de las obras proponiendo soluciones viables para las cuestiones que se formulaban como problemas en un lugar y unas circunstancias singulares, de modo que se convirtieron en un medio de

27 J. SANCHIS SIVERA, op. cit., 1925, pp. 30 y 44, para los maestros de obras; J. SANCHIS SIVERA, "La escultura valenciana en la Edad Media", Archivo de Arte Valenciano, X (1924), pp. 4 y 16; L. TRAMOYERES BLASCO, "Los artesonados de la antigua Casa Municipal de Valencia", Archivo de Arte Valenciano, III (1917), pp. 41-42. Más datos sobre este linaje de maestros de obras y carpinteros en M. MIQUEL JUAN, op. cit., 2010b, pp. 111, 114, 116-120 y 123-124.

${ }_{28}$ Agradezco a Teresa Izquierdo Aranda que llamara mi atención sobre esta noticia, extraída de los libros del AMV: Sotsobreria de Murs i Valls, d3-5, f. 130v, donde se cita a Johanet del Poyo, junto con Bertomeu, como moços del carpintero Domingo Beneyto, con un salario de 2 sueldos al día en la obra del Portal de Serranos en 1393. Para la trayectoria posterior de Joan del Poyo véase A. SERRA DESFILIS, "Al servicio de la ciudad: Joan del Poyo y la práctica de la arquitectura en Valencia (1402-1439)", Ars longa, 5 (1994), pp. 111-119.

29 A. SERRA DESFILIS, "Promotores, tradiciones e innovación en la arquitectura valenciana del siglo XV”, Goya, 334 (2011), pp. 58-73, en especial, pp. 64-68. 
intercambio de conocimientos notable ${ }^{30}$. Algunas de estas reuniones tienen el interés de mostrar cómo el radio de acción de las consultas, que en la seo gerundense es sólo regional, fue ampliándose y propició de este modo el encuentro de trayectorias de intersección improbable. La elevación y la reconstrucción del cimborrio en la Catedral de Zaragoza atrajo a la ciudad a varias generaciones de maestros destacados entre 1380 y 1505 que forman una nómina impresionante: Bernat Roca, maestro mayor de la Catedral de Barcelona (1380), Juan de Barbastro (1403), Isembart y Corlat del Rey (1417), Juan de Olótzaga, de Huesca, Pere Compte (1498, quizá 1500 y con seguridad en 1504), de Valencia, Mossén Pedro Carlos (1500), de Monteraragón, Joan Font (1500) de Barcelona, y Enrique Egas (1504) ${ }^{31}$. A veces eran los maestros quienes viajaban al lugar, como Pere Compte en sus visitas a Zaragoza y Orihuela, o Joan Font, que, además de acudir a Zaragoza, fue llamado a Córdoba a consultas por el rey Fernando el Católico y a Reus, a propósito de la Iglesia prioral de San Pedro ${ }^{32}$; otras veces, la traza servía para que el promotor resolviese sus dudas consultando a los maestros en su lugar de residencia como hicieron los ediles de Gerona al acudir a Valencia para deliberar con Antoni Dalmau en su propia casa, donde también estuvieron presentes Pedro Antonio, vecino de Alicante, Joan Trescoll, de Igualada, Joan Martí, Joan Eximeno, alias Joan de Segorbe, Miquel Navarro, Joan de Caritat, oriundo de Gascuña, y Lois Roca, canteros; todos habitantes de la ciudad de Valencia; y después en la lonja de cantería del Portal de Quart, con el maestro Jaume Pérez, Guillem Álvarez, Guillem Osset y Pere Marti ${ }^{33}$.

Otros factores sociales atañen al medio en que se instruye a los artífices. El marco de la corporación de oficio o del gremio es quizá el más reconocible de todos, aunque su importancia se haya exagerado tal vez para el período que nos ocupa, entre otras razones porque su institucionalización es algo tardía, si se compara la Corona de Aragón con otros territorios europeos como Francia o Alemania. Los estatutos de las corporaciones llegan a definir niveles de formación y las tareas para las que capacitan, pero guardan silencio a propósito del sistema de transmisión del conocimiento en sí mismo. La corporación puede verificar el grado de preparación del aspirante y procura reservar competencias para los más capacitados, pero no administra la transmisión del saber técnico ni puede regular con eficacia el entendimiento entre maestros y clientes. Las fuentes atestiguan, por ejemplo, la nostalgia de los maestros constructores de Gerona al recordar que su oficio era antes "arte grande y abundante en maestros sabios y sutiles en la cantería, la mazonería, la geometría y otras cosas propias de dicho arte" pero hacia 1480 "dichos artesanos

30 F. ESPAÑOL BERTRAN, op. cit., 1997, pp. 95-97.

31 J. IBÁÑEZ FERNÁNDEZ, Los cimborrios aragoneses del siglo XVI, Tarazona, 2006, pp. 1-25, para una revisión de la documentación y un estudio del proceso constructivo y los artífices que participaron en él.

32 M. CARBONELL I BUADES, op. cit., 2008, pp. 130 y 138.

33 A. ZARAGOZÁ y M. GÓMEZ-FERRER, op. cit., 2007, pp. 24-29, donde se da noticia de los maestros consultados en la primera reunión, pero se deja de lado el segundo encuentro con los canteros del Portal de Quart, que consta en el documento transcrito en pp. 403-405. 
y ancianos en dichos oficios asumen todos los cargos de la cofradía [de los Cuatro Santos Mártires Coronados, fundada en 1419] y llegan a morir de hambre" sin que los jóvenes quieran tomar el relevo, pues en la corporación se hallaban "los indoctos como los sabios". Por "indoctos" se entendía a personas "que no dudan en emprender obras pesadas y grandes, tales que su discreción y capacidad no pueden abarcar (...) sin haber experimentado sus conocimientos ni asumir los cargos de la cofradía, comen el pan y se apropian de los beneficios de los antiguos cofrades" La falta de formación de los jóvenes y el deseo de controlar la adquisición de conocimientos mediante un examen y poner coto a la competencia de los extranjeros en un contexto de crisis económica fueron los motivos por los que la antigua cofradía de oficio se reorganizó en 1480.

En la Corona de Aragón destacan las ordenanzas de Barcelona, Mallorca, Zaragoza y Valencia, que procuran definir grados de capacitación y las pruebas necesarias para alcanzarlos así como delimitar las competencias de cada uno de ellos ${ }^{35}$. Con todo, es más bien poco lo que se dice sobre en qué consistían tales conocimientos más allá de alusiones a la geometría, el buen oficio o la capacidad para resolver problemas constructivos concretos ${ }^{36}$. En el caso valenciano, los oficios más empeñados en el mundo de la construcción eran los obreros de villa o albañiles (obrers

34 "Era art en dita Ciutat gran e abundos de mestres sabuts e subtils en la picapedreria, mansoneria, geometría e coses altres pertanyents a dita art (...) los dits artesans e vells en dits oficis posat en si porten tots los càrrechs de dita confraria venen a perir de fam (...) los indoctes com los sabuts (...) qui no dubten emprendre obres ponderoses e grans, e tals que lur discreció e capacitat no pot comprendre (...) sens haver experimentat de lur saberia sens comportar los càrrechs de dita confraria, mengen lo pà e occupen los guanys dels dits antichs confrares". Noticia citada e interpretada por F. ESPAÑOL BERTRAN, op. cit., 1997, p. 101. Sobre el carácter de esta cofradía como auténtica corporación véase S. VICTOR, La construcció i els seus oficis a la Girona del segle XV, Girona, 2004, pp. 208-216.

35 La primera edición de las ordenanzas de Barcelona se remonta a fines del siglo XVIII y se debe a A. DE CAMPMANY Y DE MONPALAU, Memorias históricas sobre la marina, comercio y artes de la antigua ciudad de Barcelona, ed. original 1779-1792, reedición anotada, Barcelona, 1961; y la sucesiva de M. DE BOFARULL Y DE SARTORIO, Gremios y cofradías de la antigua Corona de Aragón, Barcelona, 1876; para Mallorca, A. PONS, "Els gremis: Capítols fabricats per lo bon govern i regiment del offici de picapedres (1405)", Boletín de la Sociedad Arqueológica Lul-liana, XXI (1926), pp. 101-104; datos sobre Barcelona y el examen de maestría del gremio de mestres de cases en 1423 pueden leerse en M. CARBONELL I BUADES, op. cit., 2003, pp. 201-202. En Barcelona, los jóvenes emparentados con miembros de la corporación recibían un trato más favorable en el examen, pues se les exigían menos pruebas de su capacidad. Para Gerona se cuenta con el trabajo de G. DOMÈNECH I CASADEVALL, Els oficis de la construcció a Girona, 1419-1833. Ofici $i$ confraria. Mestres de cases, picapedrers, fusters i escultors a Girona, Girona, 2001, acerca de Mallorca, I. GARAU LLOMPART, "Les ordenances del gremi de picapedrers de $1405 \mathrm{i}$ altres disposicions posteriors", Randa, 29 (1991), pp. 75-84; sobre las corporaciones aragonesas puede consultarse M.I. FALCÓN PÉREZ, Ordenanzas y otros documentos complementarios relativos a las Corporaciones de oficio en el Reino de Aragón en la Edad Media, Zaragoza, 1997. Véase ahora la revisión del tema a cargo de E. GAROFALO, Le arte del construire. Corporazioni edili, mestieri e regole nel Mediterraneo aragonese (XV-XVI secolo), Palermo, 2010.

${ }_{36}$ M. FALOMIR FAUS, Arte en Valencia, 1472-1522, Valencia, 1996, pp. 193-208; M. MIQUEL, E. MONTERO y A. SERRA, "Factors of technical innovation in Valencian architecture during the Medieval and Modern Ages: learning, know-how and inspiring admiration”, M. DUNKELD et alii (eds.), Proceedings of the Second International Congress on Construction History, vol. 2, Cambridge, 2006, pp. 2203-2222; A. ZARAGOZÁ y M. GÓMEZ-FERRER, op. cit., 2007, pp. 215-237. 
de vila), los canteros (pedrapiquers) y los carpinteros (fusters). De entre ellos se reclutaron a los maestros que dirigían las obras públicas y privadas, civiles y religiosas en los siglos XIV y XV. A lo largo del siglo XV todos se constituyeron en corporación de oficio, aunque contaban con precedentes en el siglo anterior como cofradías o asociaciones de solidaridad (almoines), que no fueron sustituidas por las nuevas instituciones pues sus funciones eran distintas y no estaban integradas por las mismas personas. Este proceso tenía un alcance más amplio que el mundo de la construcción, ya que en él participaron casi todos los oficios. Aparte de una relativa autonomía y un reconocimiento institucional, las corporaciones pretendían someter a la mano de obra a un examen cualitativo para establecer unos cánones

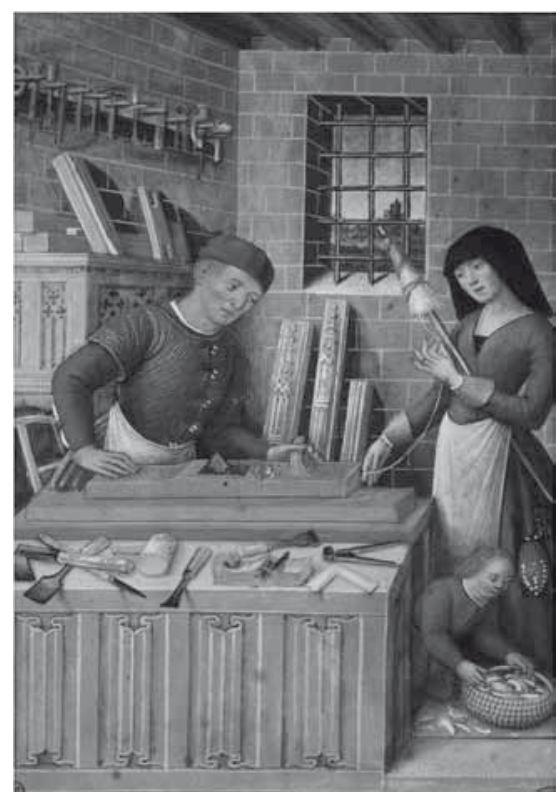

Fig. 1. Jean de Bourdichon, Les Quatre États de la Societé, miniatura del taller de un carpintero (Bibliothèque de l'École Supérieure des Beaux Arts, París). y limitar el número de maestros plenamente capacitados, además de procurar el equilibrio entre la oferta y la demanda en un mercado casi volátil a veces ${ }^{37}$ (fig. 1).

Los carpinteros comenzaron su andadura en el siglo XIV como cofradía bajo el patrocinio de san Lucas, con capilla propia en la Iglesia de San Juan del Mercado e intenciones solidarias, si bien cobraron fuerza como corporación de oficio reunida en torno al trabajo con la madera en 1424. Desde el principio se limita el acceso de los extranjeros, que deben pasar una prueba de idoneidad, la práctica del oficio queda vedada a los no cristianos y se establece un examen de maestría para garantizar la calidad y controlar la oferta en el mercado local. Los grados de competencia distinguen al aprendiz, al oficial y al maestro, pero en 1459 se contempla también la figura del asalariado en el taller y la intervención de los esclavos o cautivos, que deben aprender también el oficio según se estipula años después. Las ordenanzas de 1474 fijan la edad mínima de 20 años para optar al título de maestro y recelan de la competencia de carpinteros "forasteros y ambulantes" (forasters e viandants) que no contribuyen a la caja común, pero apenas se precisa en qué consistía el examen de maestría ${ }^{38}$.

37 P. IRADIEL, "Corporaciones de oficio, acción política y sociedad civil en Valencia", Cofradías, gremios y solidaridades en la Europa medieval (XIX Semana de Estudios Medievales. Estella, 20 al 24 de julio de 1992), Pamplona, 1993, pp. 253-284, en especial pp. 272-273.

38 T. IZQUIERDO ARANDA, "L'ofici i almoina de fusters de la València medieval”, A. SERRA DESFILIS (ed.), op. cit., 2010, pp. 377-414. 
Los obrers de vila se constituyeron en 1415 con la autorización del monarca Fernando I, pero hasta 1442 no parecen haber dejado de ser una rama de la poderosa corporación de oficio de los carpinteros, con quienes compartían representación en el Consejo municipal de Valencia. Diez años más tarde, fueron aprobados nuevos estatutos que prohibían la competencia desleal, la contratación de mano de obra esclava mientras hubiera obreros o ayudantes disponibles en la plaza donde se les reclutaba, y establecieron que se pagara como oficial a un peón si era éste quien obraba con sus manos ${ }^{39}$. En 1491, la especialización de su trabajo, la voluntad de autonomía y el aumento de la demanda en la construcción precipitaron la neta institucionalización del oficio de los obrers de vila. En consecuencia, se adoptaron normas profesionales tendentes a definir las competencias y la solvencia de quienes actuaran como albañiles o maestros de obras. En principio, contemplaron dos vías para el acceso a la maestría: un aprendizaje previo de cuatro años junto a un maestro o la presentación directa al examen, pero requería en todo caso la licencia de los mayorales como dirigentes de la corporación. La razón aducida en 1491 era que "algunos queriendo hacerse pasar por maestros o expertos en aquello que ignoran a veces han asumido algunas obras $\mathrm{y}$, como no son diestros, yerran, por lo que no sólo se causaba daño a las gentes sino incluso infamia a los maestros y prohombres del oficio". El examen se tornó obligatorio en 1496 y consistía en dos pruebas: en la primera el aspirante dibujaba una obra y en la segunda debía ejecutarla después de responder a las preguntas teóricas de los examinadores, que versaban sobre el vocabulario arquitectónico y la geometría práctica. Desde el principio, quiso limitarse el número de miembros de la corporación a un centenar y en 1491 exigieron en sus estatutos que no se contratara a maestros foráneos mientras hubiera mano de obra disponible local para controlar la competencia. En 1514 se exigió que los contratos de aprendizaje se formalizasen ante un notario ${ }^{40}$.

Los canteros se constituyeron como corporación de oficio más tarde, en 1472, aunque existía una cofradía desde 1390, bajo el patrocinio de Santa Lucía ${ }^{41}$. Los primeros estatutos empiezan invocando la antigüedad del oficio en la ciudad al tiempo que declaran la voluntad de atajar algunos abusos. Para ello establecen tres categorías -maestro, oficial (menestral) y aprendiz- y regulan el acceso a las superiores mediante un examen, después de pagar los derechos correspondientes y tras un período mínimo de aprendizaje de cinco años para optar a la maestría y de cuatro para convertirse en oficial. A fin de poner coto a la competencia exterior, los

39 J. CASTILLO y L.P. MARTÍNEZ, Els gremis medievals en les fonts oficials. El fons de la Governació del Regne de València en temps d'Alfons el Magnànim, Valencia, 1999, pp. 263-265.

40 AMV, Gremis, Caja 14, número 15, ff. 1-98, Capítols e ordinacions concordades entre los mestres d'obrers de vila.

${ }^{41}$ M. FALOMIR, op. cit., 1996, pp. 193-203 con el estudio de la corporación y su papel en la arquitectura entre los siglos XV y XVI, y pp. 531-537, donde se transcriben los documentos; A. ZARAGOZÁ y M. GÓMEZ-FERRER, op. cit., 2007, pp. 215-236, para el análisis y contexto de las ordenanzas de 1472 y 1495 , y pp. 322-324, 360-363 (para las transcripciones). 
derechos de examen se incrementan para los aspirantes forasteros según procedan de tierras de la Corona de Aragón (doble) o de otros países (triple), aunque se les exime del período de aprendizaje obligatorio para los jóvenes aspirantes locales. El sistema de transmisión del conocimiento está regulado también por el vínculo entre maestro y aprendiz, que no puede romperse para pasar a un obrador distinto de aquel en el que el joven se esté formando y favorece a los propios hijos; a su vez, cada maestro no podrá tener a su cargo más de dos mozos, ya sean aprendices o asalariados (moços de soldada). En todo caso, queda clara la intención de limitar la práctica del oficio a una nómina de sólo tres maestros y veinticuatro oficiales, todos citados por su nombre y apellido.

Los estatutos corporativos de 1495 son más prolijos e insistentes. Al distinguir las tres categorías profesionales se les atribuyen conocimientos y competencias precisas. El oficial, ahora llamado también menestral o artista, sólo puede "obrar la piedra que le es trazada por el maestro", pues de éste se exige además de ser capaz de trabajar la piedra, que también "sepa elegir y ordenar con el compás y regla todas aquellas cosas que corresponde saber al maestro". Más concretamente, los oficiales podían emprender y cobrar por sí mismos "arcos, portales, ventanas y esquinas de casas" mientras que el resto de obras "así como iglesias, claustros y otras obras mayores y menores" quedan reservadas a los maestros, título que a la sazón ostentaban sólo cuatro artífices (Pere Compte, García de Toledo, Joan Corbera y Antoni Queralt). El sistema de aprendizaje sigue regulado: puesto que los oficiales no pueden "obrar con sus manos sino lo que es trazado y ordenado por el maestro de la obra", tampoco les será permitido tener mozos o ayudantes, de los cuales cada maestro puede asumir dos como aprendices o asalariados. Con todo, se contempla un número reducido de 13 oficiales que por su experiencia, arraigo en la ciudad y ser cabezas de familia pueden tener un aprendiz sólo en calidad de ayudante. Todos los canteros son requeridos a avecindarse en Valencia y en caso de ser forasteros deben pagar aun más cuantiosos derechos de examen y someterse a una prueba para ejercer el oficio en la ciudad, aunque el importe puede reducirse si el aspirante lleva cuatro o cinco años en el equipo de un maestro local y se convierte en vecino de Valencia.

En las dos redacciones de las ordenanzas se aprecia la voluntad de controlar la competencia de forasteros, la solvencia del oficio y la jerarquía en el conocimiento técnico, severamente regulada en grados y capacidades, todo en respuesta a un mercado limitado en el que concurren maestros y promotores en vísperas de un cambio decisivo: la expansión de la albañilería y la llegada de un nuevo lenguaje arquitectónico a la romana pondrán en jaque el predominio del "arte de la piedra" en el primer cuarto del siglo XVI ${ }^{42}$. Si en parte muchas de estas inquietudes palpitan en los estatutos de las corporaciones afines como los carpinteros o los albañi-

42 J. BÉRCHEZ, Arquitectura renacentista valenciana (1500-1570), Valencia, 1995, pp. 28-62. 


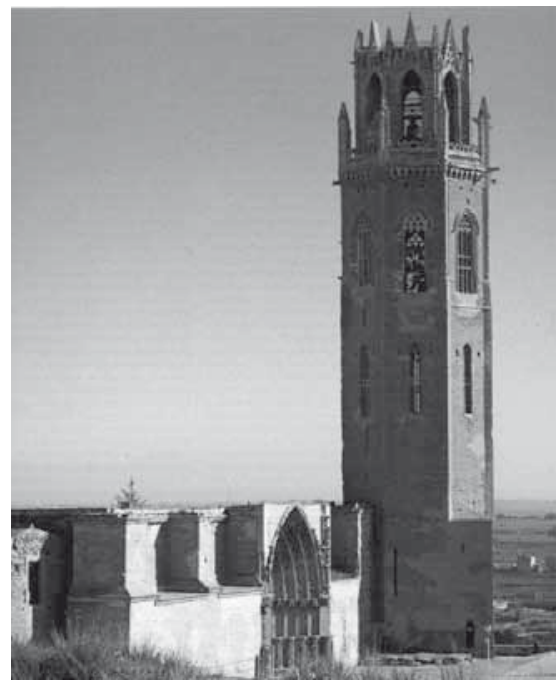

Fig. 2. Seu Vella de Lérida, Campanario.

les y, por extensión en muchos otros oficios, en el caso de los canteros llama la atención la escueta lista de maestros y la también ceñida nómina de oficiales como síntoma de restricción de la competencia de forasteros. Por otro lado, no deja de sorprender que la práctica de Pere Compte, uno de los pocos maestros de la corporación que fue también promotor de estas ordenanzas, las conculcase a lo largo de los años de su trayectoria en que estuvieron vigentes $^{43}$ (fig. 2).

\section{A pie de obra}

En la baja Edad Media, las canterías de grandes obras son también un ambiente propicio para la circulación de las técnicas, pues favorecen el contacto entre personas y el intercambio de saberes, a la vez que el aprendizaje y la enseñanza. Las grandes empresas constructivas cuentan con una concentración de medios materiales y humanos que puede mantenerse en el tiempo a corto o medio plazo, propiciando la puesta a punto de técnicas, herramientas y formas de organización del trabajo, así como la formación de varias promociones de artífices. En este aspecto cada obra define su propio modelo de fábrica como se deduce de la comparación entre las catedrales mejor estudiadas, pues había tradiciones locales y necesidades distintas según el peso de las finanzas de la seo en la economía territorial ${ }^{44}$. En todo caso, el papel de las catedrales como escenarios del aprendizaje de los maestros de obras apenas parece discutible y tenía un radio de acción bastante extenso: la Catedral de Barcelona vio sucederse a personajes de la talla de Jaume Fabre, Bernat Roca, Arnau Bargués (+1413) o Bertomeu Gual (+1442), quienes mantuvieron la continuidad de la transmisión de conocimientos entre principios del siglo XIV y comienzos del XV. Desde allí contribuyeron probablemente a la renovación arquitectónica valenciana del siglo XV a través de la familia Llobet, pues Martí cumplió una etapa de aprendizaje en la catedral barcelonesa que no le impidió conformar algunas de sus intervenciones como maestro de la catedral valentina a modelos y tradiciones

${ }^{43}$ El contrapunto entre la actividad de Pere Compte y la letra y el espíritu de estas normas así lo pone de manifiesto e invita a reflexionar sobre la vigencia efectiva de las ordenanzas. Véase A. ZARAGOZÁ y M. GÓMEZ-FERRER, op. cit., 2007, pp. 215-236.

44 J. DOMENGE I MESQUIDA, L'obra de la seu. El procés de construcció de la catedral de Mallorca en el tres-cents, Palma de Mallorca, 1997; V. ALMUNI BALADA, La catedral de Tortosa als segles del gòtic, 2 vols., Benicarló, 2007, en especial, pp. 49-249 y 437-570. 
locales ${ }^{45}$. Más tarde, el propio Bertomeu Gual viajó hasta Valencia, acompañado de un carpintero, para estudiar el cimborrio ${ }^{46}$. Igualmente el trasiego de maestros entre las seos de Tortosa y Valencia fue un medio para abrir una vía de intercambio entre estos dos centros durante casi doscientos años con consecuencias palpables, sobre todo en el territorio valenciano de la diócesis de Tortosa, en lugares como Sant Mateu o Morella ${ }^{47}$. En un espacio más amplio, la circulación entre las fábricas de las dos sedes se integra en la red que formaban las catedrales de la Corona de Aragón, con los nudos principales en Lérida, Tortosa y Valencia, por una parte, y Gerona, Barcelona y Mallorca, por otra. En la Catedral de Valencia, tras los nombres conocidos de Arnau Vidal, Nicolás de Ancona y Andreu Julià, que abarcan desde 1262 hasta la segunda mitad del siglo XIV, la secuencia es completa y relativamente

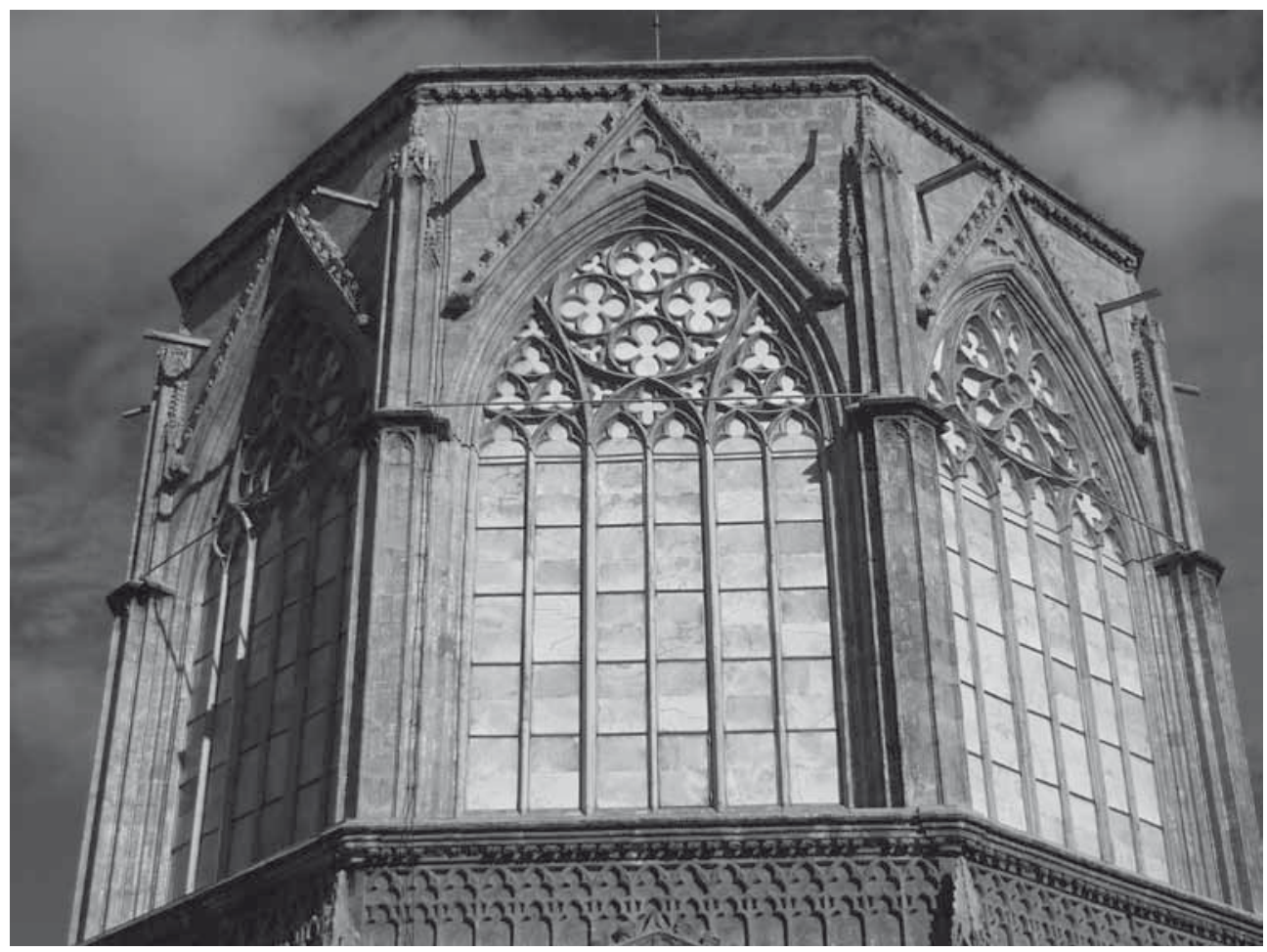

Fig. 3. Catedral de Valencia, Cimborrio, detalle.

45 M. MIQUEL JUAN, "Entre la formación y la tradición: Martí Llobet a cargo de las obras de la catedral de Valencia”, Espacio, Tiempo y Forma, 22-23 (2009-2010), pp. 13-44.

46 Noticia conocida desde antiguo y muchas veces citada. F. CARRERAS CANDI, "Les obres de la catedral de Barcelona, 1298-1415)", Boletín de la Real Academia de Buenas Letras, VII (1913-1914), pp. 302-317, la referencia en p. 313.

47 A. ZARAGOZÁ CATALÁN, "La iglesia arciprestal de Sant Mateu”, Boletín del Centro de Estudios del Maestrazgo, 73 (2005), pp. 5-40; V. ALMUNI BALADA, op. cit., 2007, pp. 5-40. 
coherente de modo que precipitó un cúmulo de experiencias y modelos en manos del taller catedralicio. Joan Franch, Pere Balaguer, Martí Llobet, Antoni Dalmau, Francesc Baldomar y Pere Compte forman una cadena de maestros mayores de la catedral que protagonizó la renovación de la arquitectura valenciana entre 1380 y $1500^{48}$ (fig. 3).

Las empresas edilicias configuran otro modelo de organización y financiación que también repercute en la discontinuidad y el vigor momentáneo de los impulsos constructivos $^{49}$. El más tardío asentamiento institucional y la necesidad de disponer de un brazo especializado de la administración municipal que gestionara las obras públicas coincidieron a menudo con la puesta en marcha de grandes proyectos, como la construcción de murallas y puertas, los puentes o un edificio singular, y terminaron por sentar las bases de una dirección técnica de los trabajos. El maestro de obras de la ciudad fue un cargo institucional con responsabilidades concretas, pero a su alrededor operaban otros constructores implicados en las obras públicas promovidas y sostenidas por el patriciado urbano que gobernaba estas ciudades. La continuidad y envergadura de este esfuerzo desde comienzos del siglo XIV hasta tiempos de Carlos V contribuyó a acumular experiencias, saberes y oficios en las ciudades, donde la competencia técnica debía confluir con la capacidad de gestión y la versatilidad, tan apreciadas por las elites dirigentes de centros como Barcelona, Zaragoza, Mallorca o Valencia, donde arquitectura y urbanismo representaban ideales de buen gobierno.

En plazos no demasiado largos, los administradores y los maestros tenían que proveerse de materiales y pertrechos, ordenar el transporte, la división del trabajo, los salarios y mantener el ritmo conveniente para la construcción, a menudo más acelerado que el de otras obras de mayor alcance temporal, como las catedrales. Además, la diversidad de actividades era una nota distintiva, aunque no exclusiva,

48 La mayor parte de la documentación conocida se debe aún a J. SANCHIS SIVERA, La catedral de Valencia, Valencia, 1909; op. cit., 1925, pp. 23-52; y "Arquitectos y escultores de la catedral de Valencia", Archivo de Arte Valenciano, XIII (1933), pp. 3-24. Las investigaciones principales sobre la actividad de los maestros citados en la catedral de Valencia son A. ZARAGOZÁ CATALÁN, Arquitectura gótica valenciana, Valencia, 2000, en especial, pp. 132-152; M. GÓMEZ-FERRER LOZANO, op. cit., 1997-1998, pp. 91-105, y la versión actualizada de este estudio por la misma autora, "El maestro de la catedral de Valencia Antoni Dalmau (act. 1435-1453)" en http://www.gothicmed.es/browsable/ca/Antoni-Dalmau.html. Sobre Francesc Baldomar y Pere Compte véase A. ZARAGOZÁ CATALÁN, "El arte del corte de piedra en la arquitectura valenciana del Cuatrocientos: Francesc Baldomar y los inicios de la estereotomía moderna", Primer Congreso de Historia del Arte Valenciano (mayo de 1992), Valencia, 1993, pp. 97-104; A. ZARAGOZÁ CATALÁN y M. GÓMEZ-FERRER LOZANO, "Francesc Baldomar", E. GAROFALO y M.R. NOBILE (eds.), op. cit., 2007, pp. 115-127; A. ZARAGOZÁ y M. GÓMEZ-FERRER, op. cit., 2007; a propósito de Martí Llobet, M. MIQUEL JUAN, op. cit., 2009-2010, pp. 13-44; para Pere Balaguer, A. SERRA DESFILIS y M. MIQUEL JUAN: "Pere Balaguer y la arquitectura valenciana entre los siglos XIV y XV", F. TABERNER (ed.), Historia de la ciudad IV. Memoria urbana, Valencia, 2005, pp. 90-111.

49 J. VIDAL FRANQUET, op. cit., 2008; A. SERRA DESFILIS, "Arquitectura y poder civil en las ciudades de la Corona de Aragón (siglos XIV-XV)", E. CARRERO SANTAMARÍA y T. SABATER RABASSA (eds.), La Ciutat de Mallorca i els segles del gòtic. XXVIII Jornades d'Estudis Històrics Locals, Palma de Mallorca, 2010, pp. 57-78, en especial, pp. 66-69. 
de los maestros de obras que trabajaban al servicio del gobierno de las ciudades en frentes que iban desde la construcción hasta el urbanismo, pasando por la defensa militar, la extinción de incendios y los preparativos de fiestas cívicas o entradas reales. Desde las magistraturas municipales el patriciado urbano fomentaba la competencia entre maestros, exigía de ellos capacidad de adaptación a toda clase de tareas y les empujaba a actuar como contratistas en el suministro de materiales, el reclutamiento de la mano de obra y la coordinación de diversos oficios ${ }^{50}$.

El aprecio por las cualidades de los mejores maestros se expresa en ocasiones en la documentación, cuando se advierte del peligro de que éstos se pusiesen al servicio de otros particulares o instituciones. Joan del Poyo, "por su famoso ejercicio", era "requerido por mucha gente notable a hacer muchas obras notables en diversas partes de la dicha ciudad y Reino" y se le ofrecían muchas compensaciones por su trabajo además del salario ordinario. Los representantes del municipio reconocían su "gran y singular suficiencia, aptitud y cualidad de experto" y no querían que abandonara las obras de la ciudad para atender otros encargos, de modo que acordaron otorgarle un salario anual de 50 florines por ejercer el cargo de maestro mayor de las obras de la ciudad ${ }^{51}$.

Tanto en el campo de las canterías catedralicias como en las obras públicas de carácter civil se observa un fenómeno semejante de especialización y división del trabajo. Por una parte, los maestros eran responsables técnicos de toda clase de tareas arquitectónicas, ingenieriles y mecánicas; por otra, los conocimientos necesarios para cumplirlas con solvencia se tornaban más especializados y complejos, de modo que bajo la supervisión general del maestro mayor laboraban verdaderos especialistas en decoración monumental, cantería, albañilería, carpintería, vidriería, yeso o ferretería, como ha quedado registrado en los libros de fábrica. El fruto maduro de esta organización arborescente fue la figura del maestro como coordinador técnico y logístico de la obra, con dotes e intereses de empresario comercial, añadidas a las de profesional experto en la construcción. Este es el perfil que definió el acuerdo del Consejo municipal valenciano en 1400 cuando otorgó a Pere Balaguer una gratificación extraordinaria de 4400 sueldos al terminar las obras del Portal de Serranos: "Por muchos y diversos trabajos que él sostuvo, y por muchas y buenas obras y provechos evidentes que ha hecho en todo momento mientras ha durado la obra de dicho portal y torres, tanto en hacer mucha y buena obra y hacerla hacer a los canteros y peones que allí obraban como en la tasación de la piedra y en muchas otras cosas que en dicho Consejo y fuera de él fueron expuestas y proclamadas" $" 52$.

50 M.M. SÁNCHEZ VERDUCH, "Maestros de obras en la Valencia gótica: personajes polifacéticos", Saitabi, 48 (1998), pp. 273-288; A. SERRA DESFILIS, "El mestre de les obres de la ciutat de València”, F. FITÉ y J. YARZA (eds.), L'Artista-Artesà medieval a la Corona d'Aragó, Lleida, 1999, pp. 399-417.

51 L. TRAMOYERES BLASCO, op. cit., 1917, p. 41.

52 "Per molts e diverses treballs per ell sostenguts, e per moltes e bones obres e profits apparents que ha fetes e fets en tot lo temps que ha durat la obra del dit portal e torres, axí en fer molta obra e bona, e fer-la 
Así el maestro mayor aparece como la persona capacitada para trazar un edificio, proveer los medios técnicos para construirlo, elegir los materiales más convenientes y tratar con los promotores de la obra haciendo valer sus conocimientos. Éstos asumen la apariencia de un secreto en la medida en que su transmisión es siempre discriminatoria respecto de las personas y del conjunto de saberes que se comunican al discípulo: no todos pueden aspirar a saberlo todo, ni mucho menos a saber cómo se hace todo cuanto sabe el maestro. Aunque se refiriese a otro oficio artístico, la declaración del pintor Antoni Peris era elocuente al respecto: "el arte del pintor es tal que si quien lo aprende no tiene sutil entendimiento, por mucho que haga el maestro no lo convertirá en discípulo apto y si el aprendiz es sutil, aprenderá bien dicho oficio aunque el maestro no ponga en ello gran diligencia"53. Además de lo aprendido, el maestro debe contrastar las reglas del oficio con el juicio fundado en la experiencia personal y el estudio de cada caso, como proponía Lorenz Lechler a su hijo Moritz ${ }^{54}$. El paso a la palabra escrita y a la imagen desde la transmisión oral y la práctica en el taller (entendido aquí como equipo humano más que como lugar de trabajo) equivale, hasta cierto punto, a la transición hacia una apertura a la difusión pública, eventualmente a través de la imprenta, de los conocimientos técnicos más avanzados, adquiridos a partir de la experiencia práctica y con el apoyo de recursos mnemotécnicos, que se prestan al intercambio con promotores, patronos y un círculo de entendidos ${ }^{55}$. En el libro de fábrica del palacio de Martín I en el monasterio de Poblet se anotó que Françoi Salau "era maestro apto y sabía entallar piedras y dictar obras y en su ausencia [de Arnau Bargués, maestro mayor] dirigía la obra, entallaba piedras y hacía muchas cosas que los otros no saben hacer", dejando constancia del papel en el control de la forma arquitectónica y el proceso constructivo de algunos artífices menos conocidos que actuaban como

fer als piquers e manobres qui alli obraven com en la taxació de la pedra e en moltes altres coses les quals en lo dit Consell e fora aquell foren rahonades e cridades", citado por M. CARBONERES, Nomenclator de las puertas, calles y plazas de Valencia, Valencia, 1873, pp. 9-10.

53 ' $L$ 'art de pintor és tal que si lo que l'apren no ha subtil enteniment per molt que faça lo mestre no.l farà covinent dexeble et si lo aprenent és subtil aprendra bé lo dit offici encara que lo mestre no.y haja gran diligència”, citado por J. ALIAGA MORELL, Els Peris i la pintura valenciana medieval, Valencia, 1996, p. 170.

54 R. MARK y L.R. SHELBY, “Late Gothic Structural Design in the 'Instructions' of Lorenz Lechler”, Architectura, 9 (1979), pp. 113-131, reeditado en L. COURTENAY (ed.), The Engineering of Medieval Cathedrals, Aldershot, 1997, pp. 87-105, en especial, p. 89.

55 Sobre el papel de la memoria en la transmisión del saber medieval véase M. CARRUTHERS, The Book of Memory, Cambridge, 1990 y The Craft of Thought. Meditation, Rethoric, and the Making of Images, 400-1200, Cambridge, 1998, pp.16-24, donde analiza el uso mnemotécnico de los edificios y su traza en planta y alzado para construir ambientes para la memoria, sobre todo en la cultura monástica; acerca del valor mnemotécnico de algunos dibujos de Villard de Honnecourt, R. BECHMANN, Villard de Honnecourt. La pensée technique au XIIIe siècle et sa communication, París, 1991, pp. 50-58; acerca de oralidad y enseñanza práctica de los oficios tradicionales son útiles los trabajos reunidos por D. CHEVALIER (ed.), Savoir faire et pouvoir transmettre: transmission et apprentissage des savoir-faire et des techniques, París, 1991; sobre el secreto y la difusión del conocimiento, P.O. LONG, Openness, Secrecy, Authorship: Technical Arts and the Culture of Knowledge from Antiquity to Renaissance, Baltimore, 2001, pp. 210-215. 
aparejadores o intermediarios entre el maestro principal y los obreros que sólo reproducían patrones ajenos ${ }^{56}$. Antoni Dalmau puso entre otras condiciones para asumir la dirección de las obras de la Catedral de Sevilla en 1449, que se contratase al equipo de aparejadores, canteros y ayudantes que trabajaban con él, sin restricciones $^{57}$ (fig. 4).

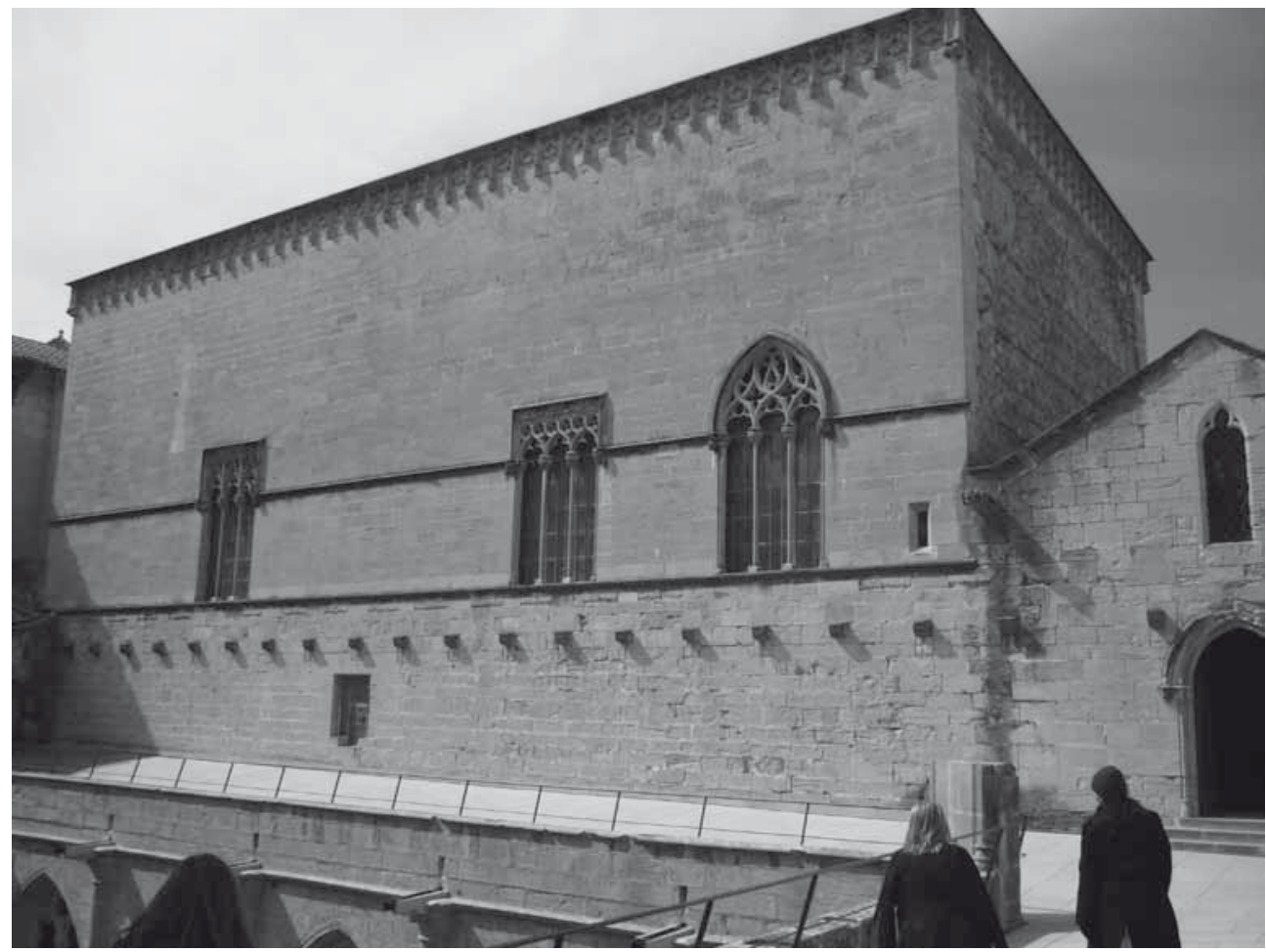

Fig. 4. Monasterio de Poblet, Palacio del rey Martín I el Humano.

La estructura del taller radicado en una ciudad, propia de los oficios artísticos en la baja Edad Media, en el mundo de la construcción corresponde mejor al grupo de canteros que viajan de un lugar a otro, buscando una obra donde sus conocimientos adquieran el valor suficiente para prosperar ${ }^{58}$. En otros territorios, se ha podido identificar un sistema de difusión del conocimiento escalonado en el tiempo y basado en la migración de obreros cualificados durante varias generaciones, a las cuales la

56 "Era apte mestre e sabia entretallar pedres e dictar obres e en absència sua regia la dita obra e entretallava pedres e fahie moltes coses qu·els altres no saben fer", citado por M.R. TERÉS I TOMÀS, "El Palau del Rei Martí a Poblet: una obra inacabada d'Arnau Bargués i Fraçoi Salau”, D’Art, 16 (1990), pp. 19-39, en especial, p. 26.

57 M. GÓMEZ-FERRER, op. cit., 1997-1998, p. 101.

58 D. KIMPEL, "La actividad constructiva en la Edad Media: estructura y evolución”, R. CASSANELLI (ed.), Talleres de arquitectura en la Edad Media, Barcelona, 1995, pp. 11-50. 
circulación permite apreciar su saber hacer y ponerlo en valor ante los promotores de las obras. La circulación de los artífices y del saber entre las generaciones pueden considerarse entonces medios privilegiados de adquisición de conocimientos, como sucede con los compagnonnages en Francia y las logias de canteros en Alemania, en los que la movilidad es un hábito profesional indisociable de la cultura del oficio ${ }^{59}$. En el ámbito hispano, las cuadrillas de canteros cántabros y vascos participaron de mecanismos de formación basados en la transmisión oral, la experiencia práctica y la movilidad que podían adaptarse a circunstancias cambiantes y obtener, lejos de sus tierras de origen, el aprecio de los promotores por las dinastías de estos maestros ${ }^{60}$. Al territorio valenciano arribaron estos grupos de canteros de la España cantábrica a partir del último cuarto del siglo XV y entraron en competencia con las corporaciones de oficio locales, pero disfrutaron de una etapa de prosperidad, sobre todo en centros secundarios, hasta bien entrado el siglo siguiente ${ }^{61}$. Sólo en la ciudad de Valencia, se han contado numerosos canteros de origen vasco-navarro (28 canteros y 8 maestros de obras de albañilería, en el período 1462-1524) ${ }^{62}$; algunos de ellos, además tienen un nombre ya reconocido, como el guipuzcoano Joan Ybarra, originario de Tolosa, quien estuvo al comienzo con Pere Compte al frente de las obras de la Lonja de mercaderes, o Domingo de Urteaga, que construyó la Iglesia de San Bartolomé de Jávea y contrató la obra de Santa María de Cocentaina. A orillas del Mediterráneo, donde encontraron trabajo y ocasiones de demostrar su pericia en la talla de la piedra, su inserción social se vio seguramente favorecida por conocimientos previos, por los vínculos mantenidos con su lugar de origen a través de la parentela y la práctica de un oficio común de un grupo de individuos integrados en una cuadrilla (fig. 5).

La familia nuclear, propia de la sociedad urbana, y la parentela más extensa podían amparar la actividad profesional y darle un impulso muy apreciable. En la Corona de Aragón la documentación notarial consiente reconstruir los árboles genealógicos de algunas dinastías de constructores como los catalanes Safont, los Sagrera mallorquines, vinculados por lazos de solidaridad familiar y profesional a partir de su trabajo en las pedreras de Felanitx ${ }^{63}$; y, en cierta medida, los Llobet

59 L. HILAIRE-PÉREZ y C. VERNA, op. cit., 2009, p. 40; M.T. ZENNER, op. cit., 2006, pp. 534-541.

60 B. ALONSO RUIZ, "La formación en la construcción durante la Edad Moderna: del 'arte de la cantería' a la profesión de arquitecto”, B. ALONSO RUIZ y O. VILLANUEVA ZUBIZARRETA (eds.), Ars et scientia. Estudios sobre arquitectos y arquitectura (siglos XIII-XXI), Valladolid, 2008, pp. 61-88.

${ }^{61}$ J. APARICI MARTÍ, "Maestros vizcaínos en la Plana de Castelló (siglos XV-XVI)", Millars. Espai i història, 29 (2006), pp. 133-150; para la comarca del valle del río Albaida véase V. TEROL REIG, J. FERRE PUERTO, “Els constructors d'esglésies: la introducció del nou llenguatge renaixentista i l'activitat dels pedrapiquers i mestres d'obra vascos i francesos a la Vall d'Albaida (segles XVI-XVII)", Actes del Primer Congrés d'Estudis de la Vall d'Albaida (Aielo de Malferit, 1996), Valencia, 1997, pp. 820-830.

${ }^{62}$ M. FALOMIR FAUS, op. cit., 1996, p. 150; además de lo expuesto por A. ZARAGOZÁ y M. GÓMEZ-FERRER, op. cit., 2007, pp. 232-234.

63 M. CARBONELL I BUADES, op. cit., 2003., pp. 181-226; M. CARBONELL I BUADES, "Sagreriana Parva", Locus amoenus, 9 (2007-2008), pp. 61-78, actualiza los datos conocidos y aporta novedades. 


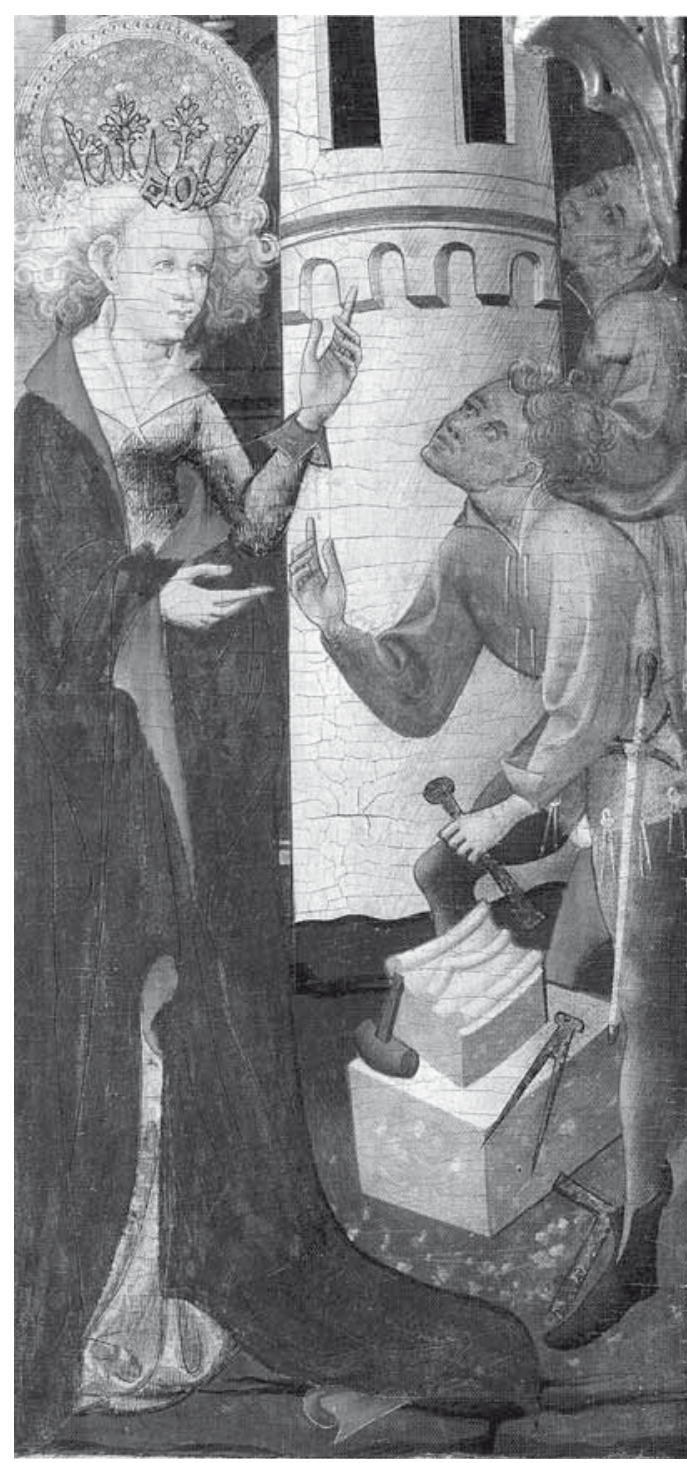

Fig. 5. Gonçal Peris (atribuida), Retablo de Santa Bárbara, detalle, procedente de Puertomingalvo (Teruel) (Museu Nacional d'Art de Catalunya). de Valencia ${ }^{64}$. Muchos artesanos combinaban las estrategias profesionales con la promoción social de la familia y los maestros de obras no escaparon a estas prácticas. Según los datos reunidos por Sandrine Victor, en la Gerona del siglo XV, la mayoría de los canteros o de los maestros de obras (el 61,7\%) no casaban a sus hijos con gentes del oficio (sólo lo hacían algo menos del 15\%) o del mundo de la construcción $(23,4 \%)$ y las hijas cumplían un papel, sobre todo en ausencia de heredero varón ${ }^{65}$. Es posible que la proximidad y el conocimiento mutuo anudaran más los lazos entre las familias de los constructores que los intereses profesionales. No obstante, si un taller establecido, unas herramientas y una posición profesional influían en la política matrimonial de los oficios de la construcción, está por ver cuál era el peso de la transmisión oral y práctica del conocimiento de padres a hijos, a la hora de favorecer la continuidad de una familia en un ámbito profesional.

\section{Viajar para conocer}

La movilidad de los maestros fue uno de los principales factores de innovación y transmisión del conocimiento. Desplazarse a otro lugar implicaba también aprender junto a un maestro, que sólo compartía su ex-

${ }^{64}$ M. MIQUEL JUAN, op. cit., 2010b, pp. 104-126.

${ }^{65}$ S. VICTOR, La construcció i els seus oficis a la Girona del segle XV, Girona, 2004 y "L'estructura familiar i social dels artifexs", A. PLADEVALL I FONT (ed.), L'art gòtic a Catalunya. Síntesi general, Barcelona, 2009, pp. 186-193. 
periencia con sus colaboradores y la enseñaba mediante la práctica, no a través de textos o modelos estandarizados. En esta edad de la arquitectura antes de la imprenta, la observación de los modelos y la transferencia del saber técnico requerían el desplazamiento de los maestros de obras o bien medios alternativos de intercambio de nociones prácticas y de ejemplos vistos por otros ojos ${ }^{66}$. Esta práctica era común en la Corona de Aragón desde mediados del siglo XIV y ha quedado registrada en la documentación cuando los promotores de las obras la fomentaban o corrían con los gastos del viaje, pero debió de haber más casos motivados por necesidades de formación u otras causas. Baste citar algunos entre los mejor conocidos. Tras asegurarse los servicios de Bernat Dalguaire para la construcción de la nueva catedral, el obispo y los canónigos de Tortosa pagaron los gastos del viaje del maestro y su ayudante a Aviñón y otros lugares "para buscar y ver obras y, vistas y buscadas, trajo de ellas traslados y trazas", itinerario cumplido entre el 27 de abril y el 31 de mayo de $1346^{67}$. En 1392 las autoridades municipales costearon el viaje de Pere Balaguer a Cataluña con el propósito de ver otros portales que le sirvieran de modelo para el de Serranos que se había de construir en Valencia ${ }^{68}$. A veces la meta del viaje era muy concreta y se justificaba por la ausencia de alternativas para transmitir las características del modelo y la necesidad de que alguien competente lo observara con la atención y la sagacidad de quien conocía su oficio. Jaume Vinader viajó en 1459 a Barcelona para ver un baño en casa de Francesc Desplà con el propósito de hacer otro semejante en

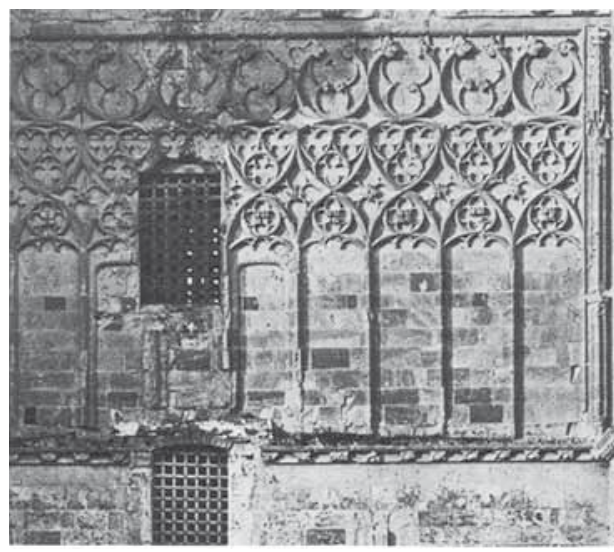

Fig. 6. Antiguo Portal de Serranos, Valencia (antes de su restauración). el Real de Valencia para la reina ${ }^{69}$ (fig. 6).

Los modelos no podían replicarse sencillamente, pues requerían adaptación. De la formación de los individuos que viajan depende su capacidad para transmitir un saber no codificado y adaptarlo al medio en el que operan. Aunque los tratados técnicos u otra clase de textos hayan servido también de medios de difusión, los vectores principales, nunca suficientes por sí solos, son las personas y los productos. En los campos de conocimiento tácito la movilidad de los artífices capacitados ha

${ }^{66}$ M. CARPO, La arquitectura en la Edad de la imprenta, Madrid, 2003, pp. 49-75; F. ESPAÑOL BERTRAN, op. cit., 1997, pp. 90-95.

${ }^{67}$ V. ALMUNI BALADA, op. cit., 2007, pp. 72-74, "per cerquar e veure obres, e vistes e cerquades d'aquells treeslats i mostres aporta".

${ }_{68}$ Noticia conocida desde antiguo y situada en la biografía del maestro por A. SERRA DESFILIS y M. MIQUEL JUAN, op. cit., 2005, pp. 93-94; 104-105.

69 J. SANCHIS SIVERA, op. cit., 1925, p. 46 
sido fundamental y la arquitectura del final de la Edad Media es uno de ellos ${ }^{70}$. Por conocimiento tácito se entiende aquel que es difícil de transmitir sólo mediante palabras, fórmulas o reglas y lo atesoran individuos y comunidades en forma de valores, creencias, destrezas, habilidades, costumbres y familiaridad con el entorno en que se opera. Este conocimiento se manifiesta en situaciones concretas pero no puede explicitarse en un currículo por lo que su transmisión no está codificada y depende de relaciones interpersonales, hasta el punto de que cobra la apariencia de un secreto ${ }^{71}$. La experiencia compartida y dilatada entre maestro y discípulo en el seno de los talleres es una forma privilegiada de adquirir esta clase de conocimientos, pero para perfeccionarla son necesarios los viajes y años de formación itinerante. La prosopografía de los maestros de obras permite seguir los pasos de individuos conscientes de su valía, de su aprendizaje y experiencias, de sus logros y del conocimiento técnico que les permitió alcanzarlos, pero no siempre es fácil por la escasez y atomización de los datos en las fuentes escritas ${ }^{72}$ (fig. 7).

La atracción que ejercían ciertos maestros y focos de innovación parece cierta. Si se conoce el origen de un maestro reputado, se comprueba que no es frecuente el triunfo

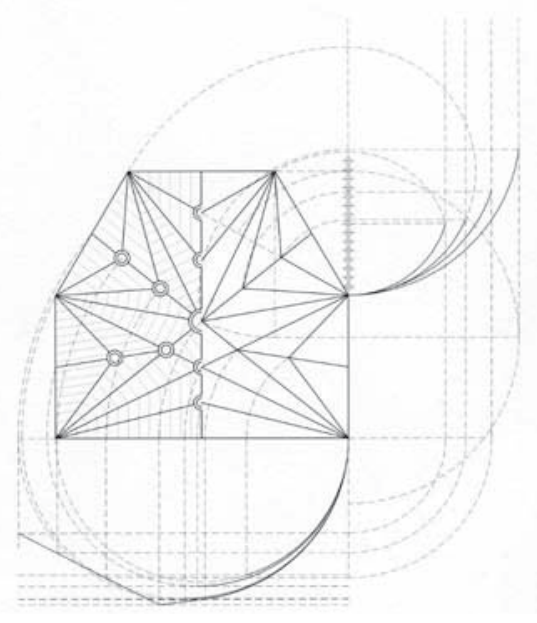

Fig. 7. Catedral de Orihuela, traza del presbiterio según Juan Carlos Navarro Fajardo. en la localidad natal y de muchos está probado que nacieron en otros lugares, a veces lejanos, por lo que no cabe pensar sólo en el atractivo de un próspero centro urbano sobre las comarcas vecinas. Era menester aprender al lado de maestros cualificados y observar de cerca las obras más admirables. Todavía en 1653 el mallorquín Josep Gelabert recomendaba en su Art del picapedrer visitar la Lonja de Palma a quienes buscasen "curiosidades, corres-

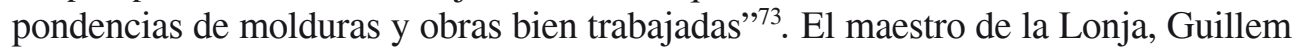

70 P. BRAUNSTEIN, "Maîtrise et transmission des connaissances techniques au Moyen Age", History of Technology, 21 (1999), pp. 155-165; P. BERNARDI, "Essai, tatonnement et pari. Le role de l'individu dans l'innovation", Médiévales, 39 (2000), pp. 14-29; S. EPSTEIN, "Journeymen, mobility, and the circulation of technical knowledge, XIVth-XVIIIth centuries", L. HILAIRE-PEREZ y A. F. GARCON (eds.), Les chemins de la nouveauté. Inventer, innover au regard de l'histoire, París, 2004, pp. 411-430; y L. HILAIREPEREZ y C. VERNA, op. cit., 2009, pp. 33-34.

71 P.O. LONG, op. cit., 2001, pp. 210-215.

72 B. ALONSO RUIZ (ed.), Los últimos arquitectos del gótico, Santander, 2010.

73 “Curiositats, correspondentias de mollures y obres ben treballades", véase J. GELABERT, De l'art de picapedrer, Palma de Mallorca, 1977. Véase E. RABASA, "De l'art de picapedrer (1653) de Josep Gelabert, un manuscrito sobre estereotomía que recoge tradiciones góticas y renacentistas", Actas del V Congreso de Historia de la Construcción (Burgos, 7 al 9 de junio de 2007), vol. 2, Burgos, 2007, pp. 745-754. 
Sagrera, nacido en una estirpe de canteros de Felanitx, comenzó su andadura en Mallorca, pasó a Perpiñán y es muy verosímil que recorriese lugares como Aviñón, Narbona o la corte borgoñona de Dijon, antes de culminar su trayectoria en Nápoles al servicio de Alfonso el Magnánimo ${ }^{74}$. Pere Compte nació en Gerona, pero debió de madurar como cantero en Valencia y desde esta ciudad se ocupó de la Iglesia de San Jaime de Villarreal (1480-1485, 1492-1493), construyó allí un puente en 1486, dirigió las obras de la Catedral de Tortosa (1490), en 1498 fue consultado sobre el cimborrio de la Catedral de Zaragoza y actuó como proyectista en 1505 para la Iglesia de Santa María de Orihuela, luego catedral ${ }^{75}$. Sin embargo, apenas sabemos nada de la formación de un maestro tan renovador de la cantería valenciana como Francesc Baldomar, quizás oriundo de Lérida, pero cuya actividad conocida se concentra en la ciudad de Valencia, de donde se le tenía por natural. Tampoco puede descartarse que el exilio forzoso de Francesc Martí alias "Biulaygua" en tierras castellanas tuviera consecuencias importantes para su formación como maestro de obras, "que fue muy sabio y muy sutil" ${ }^{16}$. En sentido contrario, no se sabe qué consecuencias tuvo el paso por Valencia de personajes como Fernando Alfonso (1396), que trabajó en el Portal de Serranos y pertenecía a una dinastía de canteros toledanos activos también en Cuenca y el Monasterio de Guadalupe o de Juan Guas en relación con la capilla de la Lonja de mercaderes ${ }^{77}$. El maestro García de Vargas, procedente de la localidad de

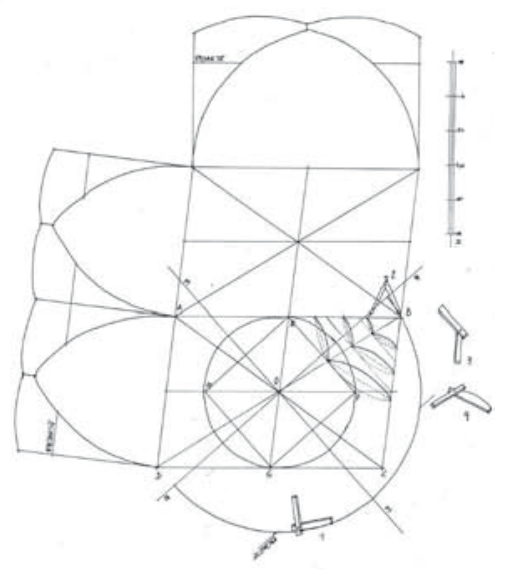

Fig. 8. Puerta de Quart, Valencia, cuerpo central. Traza de la bóveda aristada según Arturo Zaragozá.

74 J. DOMENGE I MESQUIDA, "Guillem Sagrera et lo modern de son temps", Revue de l'art, 166 (2009), pp. 77-90, quien subraya las relaciones con Francia meridional y el ámbito borgoñón.

75 A. ZARAGOZÁ y M. GÓMEZ-FERRER, op. cit., 2007, con la bibliografía allí reunida.

${ }^{76}$ Tras haber matado a otro hombre, Francesc Martí tuvo que exiliarse en Castilla, donde alcanzó notoriedad en su oficio, pues "fon molt sabut e soptil maestre de vila", pero a su regreso a Valencia parecen haber sido más bien las cualidades de su mujer como nodriza las que despejaron el camino hacia la prosperidad. Su esposa había criado gratis a una hija del Racional Guillem Çaera, y éste, hombre influyente en la Valencia de entonces, recompensó al maestro de obras poniéndolo al frente de los principales proyectos de la ciudad y reino. Véase, J. SANCHIS SIVERA (ed.), Dietari del capellà d'Anfos el Magnànim, Valencia, 1932, p. 425.

77 G. PALOMO FERNÁNDEZ, "Algunas precisiones y nuevos datos en torno a los Alfonso: una familia de canteros del arzobispado de Toledo (1383-1431)", Archivo Español de Arte, 292 (2000), pp. 341-360. Véase también J. MARTÍNEZ DE AGUIRRE, "Investigaciones sobre arquitectos y talleres de construcción en la España medieval cristiana", Anales de Historia del Arte. Cien años de investigación sobre arquitectura medieval española, vol. ext. (2009), pp. 127-163, en particular, p. 152. Juan Guas recibió 15 libras en mayo de 1484 por su participación en la capilla de la Lonja de Valencia, si es el mismo Juan de Córdoba citado en las fuentes valencianas, y un cierto Dionís Guas aparece documentado en Valencia, sin que conste un parentesco entre ambos. A. ZARAGOZÁ y M. GÓMEZ-FERRER, op. cit., 2007, p. 86. 
Bargas (Toledo), quien aparece en las fuentes valencianas como García de Toledo, fue uno de los tres maestros canteros reconocidos en los estatutos de la corporación en 1472 y participó en las obras del Portal de Quart, la catedral, la capilla de los Joan en la Iglesia de San Juan del Hospital, el Palacio de los duques de Gandía y la Capilla funeraria de Joan de Vich en Valencia, pero es difícil discernir todavía cuál fue su papel en este contexto de experimentación ${ }^{78}$ (fig. 8).

\section{Mostrar y representar}

El estudio del dibujo en la arquitectura gótica ha sido explorado por varias generaciones de estudiosos ${ }^{79}$. La traza o la maqueta tridimensional, los dibujos de montea y las plantas han tenido un papel fundamental en la toma de decisiones y la definición

78 A. ZARAGOZÁ y M. GÓMEZ-FERRER, op. cit., 2007, pp. 229-230, donde se recoge su actividad valenciana, así como las últimas noticias en el artículo de J. CORBALÁN DE CELIS Y DURÁN y M. GÓMEZ-FERRER LOZANO, "La capilla funeraria de Joan de Vich en Valencia (1494-1495): La participación de Joan Corbera, García de Vargas y Pablo Forment”, Archivo de Arte Valenciano, 90 (2009), pp. 43-53.

79 Un trabajo pionero se debe a H. ROSENAU, Design and Medieval Architecture, London, 1934; tras ella, los artículos de F. BUCHER, "Design in Gothic Architecture. A Preliminary Assessment", Journal of the Society of Architectural Historians, 27 (1968), pp. 49-71 y "Medieval Architectural Design Methods, 800-1560", Gesta, 11 (1972), pp. 37-51; y el corpus editado por el mismo autor Architector. The Lodge Books and Sketchbooks of Medieval Architects, New York, 1979; la síntesis de W. SCHÖLLER, "Le dessin d'architecture en epoque gothique", R. RECHT (ed.), Les bâtisseurs des cathédrales gothiques, Strasbourg, 1989, pp. 226-235; W. SCHÖLLER, "Ritzzeichnungen: Ein Beitrag zur Geschichte der Architekturzeichnung im Mittelalter", Architectura, 19 (1989), pp. 31-61, que incluye un catálogo de dibujos de montea (pp. 47-61), W. SCHÖLLER, "Die Entwicklung der Architekturzeichnung in der Hochgotik", Dresdener Beiträge zur Geschichte der Technikwissenschaften, 23/1 (1994), pp. $2-9$ y 24/1 (1994), pp. 39-48; R. RECHT, Le dessin d'architecture. Origine et fonctions, París, 1995; J. ACKERMAN, The Reinvention of Architectural Drawing, 1250-1550, London, 1998, trata la cuestión del dibujo arquitectónico en este período; sobre Italia, F. TOKER, "Building on paper: the role of architectural drawing in late medieval Italy", A.M. ROMANINI (ed.), L'art et des revolutions. XXIIe Congrès International d'Histoire de l'Art, Section 8 (septembre 1989), Strasboug, 1992, pp. 31-50; y en especial, V. ASCANI, Il Trecento disegnato. Le basi progettuali dell'architettura gotica in Italia, Roma, 1997; M. BORGHERINI, Disegno e progetto nel cantiere medievale. Esempi toscani del XIV secolo, Venezia, 2001; para Inglaterra se dispone ahora del estudio de A. PACEY, Medieval Architectural Drawing. English Craftsmen's Methods and their Later Persistence, Stroud, 2007, quien se ocupa también de carpinteros y escultores, además de los canteros; notable es el catálogo de la rica colección de la Academia de Bellas Artes de Viena, J.J. BÖKER, Die Architektur der Gotik. Bestandskatalog der weltgrössten Sammlung an gothischen Baurissen der Akademie bildenden Künste Wien, Salzburg, 2005; J.A. RUIZ DE LA ROSA, Traza y simetría de la Arquitectura en la Antigüedad y el Medievo, Sevilla, 1987, repasa la historia del dibujo desde la Antigüedad hasta el gótico, vinculando al sistema gremial y al predominio de la geometría en esta arquitectura el auge de la traza a partir del siglo XIII, véase también J.A. RUIZ DE LA ROSA, "El arquitecto en la Edad Media", A. GRACIANI (ed.), La técnica de la arquitectura medieval, Sevilla, 2001, pp. 151-174; F. MARÍAS, "Trazas, trazas, trazas: tipos y funciones del dibujo arquitectónico", M.A. ARAMBURU ZABALA y J. GÓMEZ MARTÍNEZ (eds.), Juan de Herrera y su influencia. Actas del simposio (Camargo, 1992), Santander, 1993, pp. 351-359; B. ALONSO RUIZ y A. JIMÉNEZ MARTÍN, La traça de la iglesia de Sevilla, Sevilla, 2009, pp. 103-117, revisan el panorama del tardogótico hispano al poner en su contexto la traza de la catedral de Sevilla conservada en el convento guipuzcoano de Bidaurreta; sobre el ámbito valenciano; A. ZARAGOZÁ CATALÁN y A. GARCÍA CODOÑER, "El dibujo de proyecto en época medieval según la documentación archivística: el episodio gótico valenciano”, M. DOCCI (ed.), Il disegno di progetto dalle origini al XVIII secolo, Roma, 1993, pp. 41-44 y recientemente las observaciones de A. ZARAGOZÁ CATALÁN, "El control de la forma en la arquitectura medieval valenciana: Dibujo y oficios artísticos durante los siglos XIII y XIV”, F. TABERNER (ed.), Historia de la ciudad VI, Valencia, 2008, pp. 80-96. 
de la forma, el tamaño y las soluciones técnicas viables de numerosas construcciones. En la documentación de la Corona de Aragón no son raras las alusiones a maquetas, dibujos y operaciones de replanteo sobre el terreno en el curso de la elaboración de un proyecto como en las discusiones sobre cómo continuarlo. El dibujo ilustraba la propuesta del maestro al tiempo que permitía debatirla y reformarla mediante el mismo lenguaje gráfico, dando lugar a una arquitectura con control remoto y plural de la fábrica. Al rematar la obra o abandonar el proyecto, los dibujos perdían su utilidad y no había motivos para conservarlos, lo que explicaría mejor su escasez que la voluntad de preservar un secreto ${ }^{80}$. Entre los ejemplos conservados en la Corona de Aragón, el más antiguo debe de remontarse a 1368 y es una traza de la planta del campanario de la Colegiata de San Félix de Gerona sobre papel, que incluye la forma y las dimensiones de la obra prevista ${ }^{81}$. De la cabecera de la Iglesia de Alcañiz se conoce una traza a través de un grafito ${ }^{82}$. En la Catedral de Tortosa sobrevivieron dos trazas, una planta y lo que parece un alzado parcial, que han sido estudiados a fondo en los últimos años ${ }^{83}$. El proyecto de Carlín (Charles Gautier) para la fachada de la Catedral de Barcelona de 1408 es conocido desde antiguo y ocupa un lugar destacado en la historia del dibujo arquitectónico. El cantero y escultor Pere Mates tenía entre sus bienes en 1358 moldes de diversos metales, imágenes en madera y yeso, tablas para tallar "muestras" y diez pliegos de papel y pergamino conteniendo "diversas mostras et figuras in pictura" $"$. Recientemente se ha llamado la atención sobre el conjunto de mostres, imatges e empints citado en el inventario de bienes del maestro Rotllí Gautier (o Vautier), que estuvo al frente de las obras de la Catedral de Lérida hasta su muerte, en 1441, después de haber recorrido los principales centros de Cataluña y el sur de Francia ${ }^{85}$. El inventario detalla material diverso, incluyendo

${ }^{8}$ F. TOKER, "Gothic Architecture by Remote Control: an Illustrated Contract of 1340", Art Bulletin, 46 (1985), pp. 67-95, a propósito del contrato para la fachada del palacio Sansedoni de Siena.

${ }^{81}$ Se atribuye a Pere Sacoma. Reproducido en el catálogo de la exposición La catedral de Girona. L'obra de la Seu, Girona: Fundació "La Caixa", 2003, p. 180; M.A. CHAMORRO TRENADO, "La construcció de l'església de Sant Feliu de Girona”, Revista de Girona, 240 (2007), pp. 73-78. Véase ahora M.A. CHAMORRO y A. ZARAGOZA CATALÁN, "La traza de la torre campanario de la iglesia de San Félix de Gerona", Goya, 338 (2012), pp. 3-15.

82 Dado a conocer por M. SIURANA ROGLÁN, "Un grafito, posible cabecera de la iglesia de Alcañiz", Teruel, 68 (1972), pp. 163-174 y citado con otras mostres de la Corona de Aragón por F. ESPAÑOL BERTRAN, op. cit., 1997, pp. 87-88.

83 J. LLUÍS I GUINOVART y V. ALMUNI BALADA, "La traça de la catedral de Tortosa. Els models d'Antoni Guarc i Bernat Dalguaire”, Lambard, IX (1996), pp. 23-37; J. LLUÍS I GUINOVART, Geometría $y$ diseño medieval en la catedral de Tortosa. La catedral no construida, Tesis doctoral inédita, Universitat Internacional de Catalunya, 2002.

${ }^{84}$ G. LLOMPART, "Pere Mates, un constructor y escultor trecentista en la Ciutat de Mallorques", Boletín de la Sociedad Arqueológica Luliana, 34 (1973), pp. 91-118.

85 Su actividad documentada en la Corona de Aragón comienza en Perpiñán en 1410, donde se relaciona con Guillem Sagrera y realiza algunos arcos en el Palau de les Corts, entre 1424-1427, pasa luego a dirigir la obra de la Catedral de Gerona (1427-1430), con posible incursión en Narbona; tuvo un periodo de actividad en Barcelona (1432-1435), donde hizo testamento en 1435 y se desplazó a Castellón de Ampurias en 1433; en su última etapa trabajó en la fachada de la Catedral de Lérida, ciudad de su muerte en 1441. Es probable 
retablos, imágenes y una tumba, además de las trazas arquitectónicas de ventanas, un gran portal, un remate de una torre, el dintel de otro portal, una traza de una capilla, pedestales y algunas columnillas. Ni siquiera todos estos objetos eran dibujos, pues varios están identificados claramente como imágenes en madera o yeso y el soporte de las trazas podía ser pergamino o papel ${ }^{86}$. En realidad, el conjunto de imágenes, dibujos y modelos no es tan distinto de los que aparecen en inventarios de bienes de muchos artistas europeos en los siglos XIV y XV y que en la documentación valenciana se registran como mostres, papers, dibuixos o denominaciones parecidas, sin que esté del todo justificado tenerlos por dibujos de proyecto $^{87}$ (fig. 9).

Aunque la traza sirve en todo caso para revelar

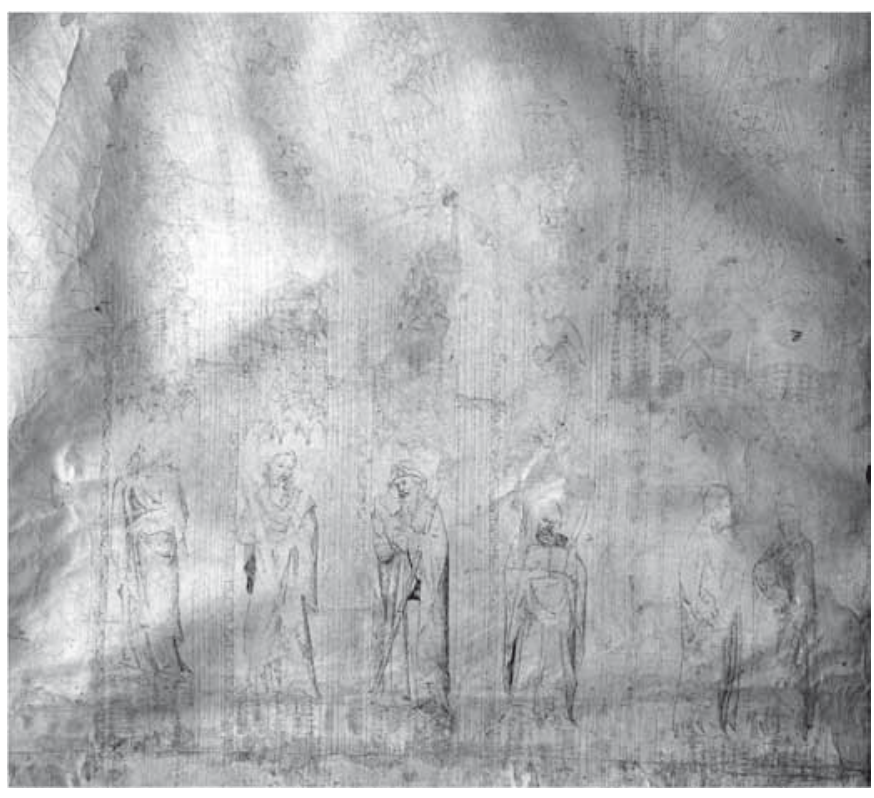

Fig. 9. Maestro Carlín, Catedral de Barcelona, traza de la fachada, detalle (Museo Catedralicio de Barcelona).

que él y su hermano Charles, o sea el maestro Carlín, procedieran de Rouen, aunque cuando Rotllí es nombrado maestro mayor en Gerona se anota que proviene de la diócesis de Verdún. Sobre este maestro véase G. ALONSO, Los maestros de la Seu Vella de Lleida y sus colaboradores, Lérida, 1976, pp. 99-113, con la referencia al inventario en p. 111; M. CARBONELL I BUADES, op. cit., 2008, p. 118, nota 39, donde apunta a los primeros pasos conocidos por ahora de su actividad en el norte de Francia; M. CARBONELL I BUADES, op. cit., 2003, pp. 190-192, donde se menciona el documento del testamento dictado en Barcelona el 16 de abril de 1435; J. VALERO MOLINA, “Acotacions cronològiques i nous mestres a l'obra del claustre de la catedral de Barcelona”, D’Art, 19 (1993), pp. 29-41; M.R. TERÉS TOMÁS, “Art i arquitectura a la Seu Vella en temps d'Alfons el Magnànim”, Seu Vella. Anuari d'Història i Cultura, 3 (2001), pp. 55-122; F. FITÉ, "L'alberg i l'inventari patrimonial de Rotllí Gaulter, escultor i mestre d'obra de la Seu de Lleida (1442)", Seu Vella. Anuari d'Història i Cultura, 3 (2001), pp. 123-147; M.R. MANOTE I CLIVILLES, "Rotllí Gautier", en A. PLADEVALL (ed.) L'art gòtic a Catalunya. Escultura II, Barcelona, 2007, pp. 152-158. Para la noticia de las obras en la Iglesia de Santa María de Castellón de Ampurias véase J. VALERO MOLINA, "Pere Oller", A. PLADEVALL, op. cit., 2007, p. 117.

86 A. ZARAGOZÁ y M. GÓMEZ-FERRER, op. cit., 2007, pp. 218-219 plantean la hipótesis de la llegada a Valencia de estos bienes a través de Andreu Pi, que fue también maestro mayor de la catedral de Lérida.

87 R.W. SCHELLER, Exemplum: Model-book Drawings and the Practice of Artistic Transmission in the Middle Ages (ca. 900-ca. 1450), Amsterdam, 1995, encuadra el dibujo arquitectónico en los libros de modelos utilizados en otros oficios artísticos durante la Edad Media; una revisión reciente que deja de lado el dibujo arquitectónico en S. NASH, Northern Renaissance Art, Oxford, 2008, pp. 167-177; para la Corona de Aragón, véase E. MONTERO TORTAJADA, "Sentido y uso de la mostra en los oficios artísticos. Valencia, 1390-1450”, Boletín del Museo e Instituto Camón Aznar, XCIV (2004), pp. 221-254. 
las innovaciones técnicas y estéticas de una obra, como herramienta de control del trabajo y de su aprobación por la clientela, es posible al menos distinguir dos tipos de dibujos en función de los destinatarios primeros. Muchas trazas debían de obedecer al propósito de perfilar y confirmar las características del encargo en el marco de las negociaciones entre artista y promotor de la obra, por lo que no es insólito

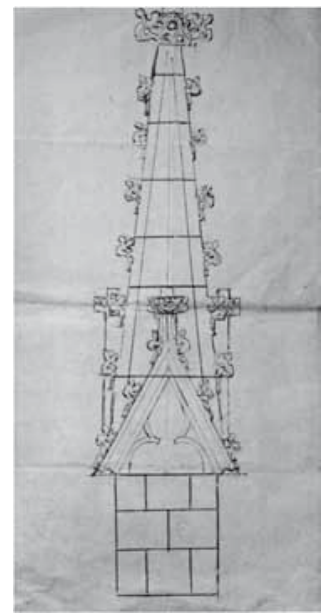

Fig. 10. Guillem Solivella (atribuida), Catedral de Lérida, traza de un pináculo (desaparecida). que se adjunten a los contratos o se aluda a ellas en los encargos; también ayudarían a convencer a clientes indecisos. En todo caso debían de ejecutarse ex profeso para cada obra en particular y tenían que ser inteligibles y sugestivas para los promotores: un formato amplio o un modelo tridimensional tenían más posibilidades de ser apreciados por los ojos de los clientes y, en última instancia, granjear el encargo para los artífices. Podían convertirse también en una exhibición de pericia o un alarde de virtuosismo, cualidades muy estimadas por los promotores entonces ${ }^{88}$ (fig. 10).

El coro de la Catedral de Valencia fue una obra de gran exigencia y parece haber generado un buen número de trazas que combinaban la exhibición con el compromiso vinculante de los artífices implicados. Joan Franch cobró 10 sueldos en 1381 por dibujar sobre pergamino una traza de un portal nuevo que debía mostrarse a un cardenal, probablemente Pedro Martínez de Luna, quien era prepósito del cabildo de Valencia y llegaría a pontífice con el título de Benedicto XIII ${ }^{89}$. El mismo Franch ejecutó otro dibujo, más acorde con la nueva sillería del coro en 1392, pero los clientes y, en particular, el canónigo Gil Sánchez Montalbán esperaban algo más. En consecuencia se contrató la obra del trascoro de la Catedral de Valencia con Guillem Solivella, a la sazón maestro de obras de la Catedral de Lérida ${ }^{90}$, en dos ocasiones, 1394 y 1397, sin éxito, pero cuando el encargó pasó a manos de Jaume Esteve muchos años después, en 1415, se aludía a lo "dibujado y pintado en un gran pergamino" y se establecía que la obra debía sujetarse en todo a dicha traza "salvo que la obra de talla debe hacerse netamente como corresponde a buen maestro", puesto que la muestra no estaba del todo aca-

${ }^{88}$ S. PERKINSON, "Engin and artifice: Describing Creative Agency at the Court of France, ca. 1400", Gesta, XLI/1 (2002), pp. 51-66; A. SERRA DESFILIS, op. cit., 2011, pp. 66-67.

89 M. MIQUEL JUAN, op. cit., 2010a, pp. 349-376, en especial, p. 353.

90 Sobre este escultor véase P. BESERAN I RAMON, "Un estil per a Guillem Solivella i d'altres hipòtesis d'escultura lleidatana trescentista", Matèria, 4 (2004), pp. 19-52, y "Guillem Solivella", A. PLADEVALL (ed.), op. cit., 2007, pp. 146-151. El intercambio de artistas entre Valencia y Lérida está bien documentado y consta, por ejemplo, que el vidriero francés Joan de Sant Amat pasó desde la ciudad del Turia a la de Lérida en julio de 1393, poco antes de que Guillem Solivella trazara el portal del trascoro, véase G. ALONSO, op. cit., 1976, pp. 48-77, en particular, p. 57. A este maestro se le atribuye el dibujo de un pináculo de la obra de la Catedral de Lérida, véase F. FITÉ I LLEVOT, "Dibuix de pinacle”, Seu Vella. L'esplendor retrobada, Lleida, 2003, pp. 57-58. 
bada y se custodiaría con la garantía de la firma notarial en la sacristía de la catedral "para memorial"91. La documentación es demasiado fragmentaria como para disipar todas las dudas y no puede descartarse que la traza de Guillem Solivella fuera aún tenida en cuenta en 1415 ni tampoco que Jaume Esteve hiciera otra nueva, pero la intrincada historia de esta empresa es uno de los mejores ejemplos de la voluntad de intervención de los promotores en la obra sirviéndose del dibujo de una pieza singular, muy visible y acaso innovadora recurriendo a diversos maestros. La maqueta de madera de una torre sobre la Cámara de los Ángeles en el Palacio del Real de Valencia permitiría a Alfonso el Magnánimo aprobar desde tierras italianas las obras entonces en curso en su residencia valenciana ${ }^{92}$. A la misma categoría corresponden las ventanas de la Sala del Consejo de la Casa de la Ciudad, diseñadas por Joan Llobet en 1425 en una traza que conservó un regidor con el visto bueno de los Jurados y que fueron tasadas más tarde por el maestro Carlín de Lérida ${ }^{93}$, o los dos dibujos del puente que se debía construir sobre el Ter en Gerona y que motivó la citada consulta de varios maestros reunidos en la casa de Antoni Dalmau y en la lonja de canteros del Portal de Quart en Valencia en $1446^{94}$. Tanto los promotores de las obras como los artífices perseguían estos dibujos como vehículos de transferencias de modelos, si bien los notarios que redactaron los inventarios parecen haberles dispensado escasa atención. La tracería y el antepecho del campanario de la Catedral de Valencia, el Micalet, debía dibujarlos Martí Llobet "bien y notablemente, según corresponde a dicho campanario, de la altura, forma y manera de la muestra hecha y entregada al capítulo y trazada por él mismo en el huerto de don Pere Daríes" "95 y el proyecto para la espiga o remate de la misma torre había atraído a otros maestros canteros a la muerte de Antoni Dalmau (1453), por lo que el fabriquero de la catedral alertó a los canónigos, quienes decidieron comprarla a la viuda del maestro por seis timbres antes que se extraviase ${ }^{96}$. La almoneda de algu-

91 J. SANCHIS SIVERA, op. cit., 1909, pp. 214-215; J. SANCHIS SIVERA, op. cit., 1924, pp. 5-9, donde se cita a "Miguel Çolivella" en vez de Guillem Solivella; J. SANCHIS SIVERA, op. cit., 1933, pp. 17-24. Las capitulaciones de 1415 con Jaume Esteve insisten en la obligación que el maestro contrae de atenerse a la traza en cuestión. Para esta obra, cuyas vicisitudes fueron largas y difíciles véase M. MIQUEL JUAN, op. cit., 2010a, pp. 352-364. El fracaso de Jaume Esteve, tras las censuras de los canónigos y el arbitraje del platero Bertomeu Coscolla y del cantero Pere Balaguer en 1422 -en el que curiosamente ya no se vuelve a aludir a la traza- dio ocasión a encomendar un nuevo trascoro en piedra de alabastro al maestro Antoni Dalmau en 1441. El portal del trascoro debía protegerse con una reja que se encargó a Antoni Gay, tras dibujar la correspondiente traza en 1422, véase J. SANCHIS SIVERA, op. cit., 1933, pp. 20-21, nota 3.

92 J. SANCHIS SIVERA, op. cit., 1925, pp. 23-54, en especial p. 42.

93 A. SERRA DESFILIS, op. cit., 2004, pp. 90-91.

94 Un dibujo, más pequeño, mostraba el puente construido a partir de un arco rebajado; el otro, mayor, representaba cómo podía elevarse un puente con tres arcadas, que fue la opción escogida por los maestros reunidos. A. ZARAGOZÁ y M. GÓMEZ-FERRER, op. cit., 2007, pp. 24-29.

95 R. CHABÁS, "El remate del Miguelete”, Almanaque Las Provincias, 1899, pp. 103-106; M. MIQUEL JUAN, op. cit., 2009-2010, p. 25.

96 J. SANCHIS SIVERA, op. cit., 1909, pp. 98-100. Sobre Dalmau, M. GÓMEZ-FERRER, op. cit., 1997-1998, p. 100. 
nos bienes que fueron del mismo Dalmau el 20 de abril de 1453 incluía un "paper de tres ymatges" que podemos tomar por dibujos de piezas escultóricas, aunque no consta el nombre de quien lo adquirióo ${ }^{97}$. El cantero Miguel de Cuenca litigó contra Jacquet de Vilans por la traza de un tabernáculo en pergamino en 1444 sin que pueda considerarse a ninguna de las partes en conflicto responsable del dibujo original, al que ambas atribuían un valor singular: Miguel de Cuenca nombró como procurador suyo al también cantero Gaspar Ferrando, residente en Orihuela " $a d$ petendum, exhigiendum et recipiendum atque habendum" del maestro Jacquet de Vilans, también establecido en la misma ciudad ${ }^{98}$ (figs. 11 y 12).

Este lenguaje figurativo servía para la comunicación entre maestros de obras, promotores e instituciones implicados en una fábrica, pero el verdadero medio de transmisión del conocimiento tuvieron que ser las trazas destinadas a los oficia-

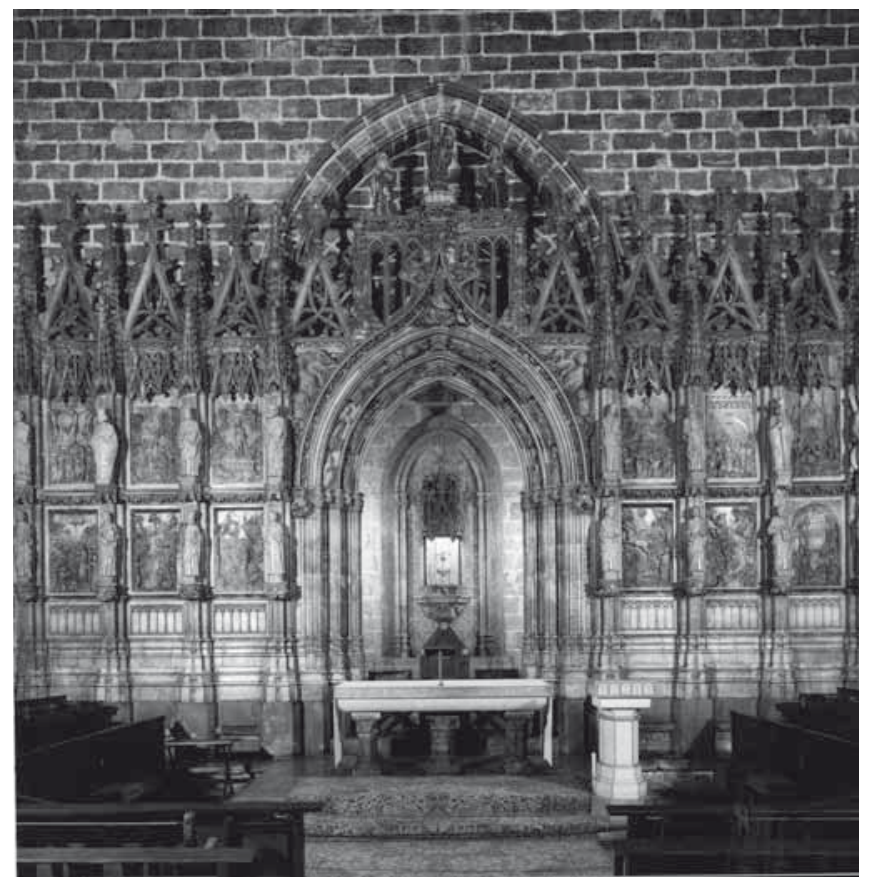

Fig. 11. Catedral de Valencia, fachada del antiguo trascoro, hoy en la Capilla del Santo Cáliz. les y ayudantes del maestro durante las obras, ya fueran planos generales 0 más comúnmente diseños de elementos constructivos y ornamentales, tales como pilares, tracerías y decoración figurativa. Algunos de ellos recaen en la categoría de patrones, plantillas y moldes, como los dibujos de montea, los perfiles de molduras y los patrones, es decir, "modelos que sirven de muestra para sacar otra cosa igual" como los define el Diccionario de la Real Academia Española. También el Diccionari català-valencià-balear de Alcover y Moll recoge el significado de mostra como "ejemplar que se ha

97 M. GÓMEZ-FERRER, op. cit., http://www.gothicmed.es/browsable/ca/Antoni-Dalmau.html, p. 37.

98 Citado por A. ZARAGOZÁ y M. GÓMEZ-FERRER, op. cit., 2007, p. 219 y transcrito en p. 403. El dibujo en pergamino iba acompañado, acaso, de una intrigante inscripción o texto ("ab son legiment" en el documento original). 


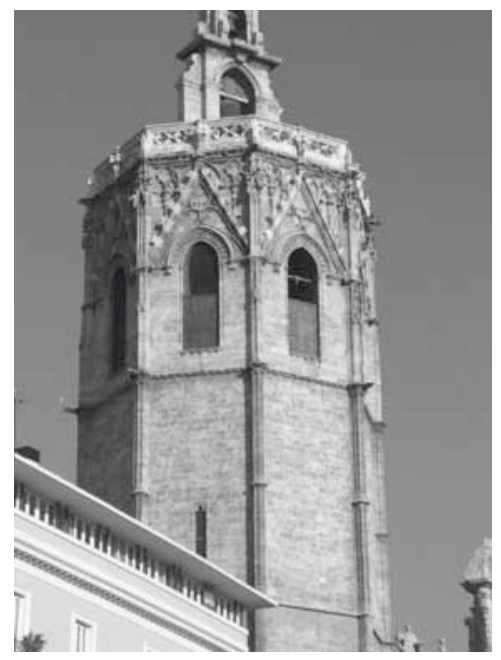

Fig. 12. Catedral de Valencia, campanario conocido como el Micalet.

de copiar o imitar" ${ }^{\prime 99}$. El valor ejemplar implicaba que el aprendiz debía ejercitarse en la copia del patrón, asimilando sus cualidades y reproduciéndolo cuantas veces fuera menester con exactitud. No puede descartarse que fueran recetarios formales que definían también el buen hacer de un obrador o un equipo de obreros, sobre todo si se trataba de detalles ornamentales o refinadas molduras, por no mencionar la decoración de "curiosidades y babuinos" que pobló espacios marginales de puertas, ventanas, impostas y cornisas ${ }^{100}$. Despierta interés y abre algunos interrogantes la noticia de un "Códice de los obrers de vila [maestros de obra], que contiene curiosos dibujos" y poseía Faustino Barberá a principios del siglo $\mathrm{XX}^{101}$, pues es difícil imaginar otro ambiente en el que pudieran sobrevivir estos patrones que no fuera el de la corporación o el taller. Como las trazas de montea, estos dibujos estarían destinados a ser reproducidos por personas distintas de quienes los ejecutaron por vez primera y podían pasar de mano en mano como modelos valiosos.

Por otra parte, no debe confundirse la traza como definición de la forma arquitectónica del dibujo como medio de expresión, pues dicha traza o muestra podía no haberse trasladado a una planta y una montea. A veces el trazado consistía en una acción de replanteo en el solar o en el edificio en obras y a tamaño natural, ante los ojos de los promotores o los clientes y seguramente también ante los menestrales de la construcción ${ }^{102}$. Las instrucciones orales y la confianza en un aparejador que las

99 A.M. ALCOVER y F.B. MOLL, Diccionari català-valencià-balear, vol. VII, Palma de Mallorca, 1988, p. 621, en la voz mostra: "Exemplar que s'ha de copiar o imitar (escrivint, pintant, obrant moralment, etc.), además de la de objecte que s'exhibeix i que indica la presència, qualitat, manera d'ésser, etc. d'alguna cosa".

${ }^{100}$ Sobre este aspecto trabaja en los últimos años la investigadora Encarna Montero Tortajada contemplando el panorama de los diversos oficios artísticos. Véanse sus publicaciones: E. MONTERO TORTAJADA, op. cit., 2004; "Emulación y superación del modelo en la documentación notarial: a imagen de una mostra, a imagen de otra obra (Valencia, 1390-1450)", Actas del XV Congreso Nacional de Historia del Arte (CEHA). Modelos, intercambios y recepción artística (de las rutas marítimas a la navegación en red) (Palma de Mallorca, 20-23 de octubre de 2004), Palma de Mallorca, 2008, pp. 145-158; y "Recetarios y papers de pintura en la documentación bajomedieval. Valencia, 1452: el ejemplo de Andreu García”, Libros con arte, arte con libros [De los códices medievales a los libros de artista: códices, tratados, libros, vehículos de comunicación creativa. Trujillo, 11 y 12 de noviembre de 2005], Trujillo, 2007, pp. 507-517.

${ }^{101}$ V. FERRÁN SALVADOR, Capillas y casas gremiales de Valencia, Valencia, 1926, p. 77.

${ }^{102}$ C. GÓMEZ URDÁÑEZ, "Vitrubio según Cervantes. Arquitectos y oficiales en la construcción en el siglo del Renacimiento", Arquitectura en construcción en Europa en época medieval y moderna, Valencia, 2010, pp. 255-285, en especial, pp. 268-276. 
transmitiera con claridad a los obreros suplían muchas de las funciones del dibujo de proyecto a la hora de dar forma a los edificios, trazados sobre el suelo, los muros o superficies de yeso dispuestas al efecto, o convertidos en plantillas y perfiles de materiales variados como yeso, madera o metal ${ }^{103}$. En noviembre de 1401 el proyecto del nuevo puente de piedra de la Trinidad en Valencia tomó forma, pues se emplearon 4 cahíces y medio de yeso para un traza del puente y el maestro cantero Francesc Tona cobró por los gastos en papel, almidón y cola por una traza en papel que los Jurados le habían ordenado para la obra del puente ${ }^{104}$. Uno de los canteros principales de la obra, probablemente el mismo Tona, modeló las plantillas de los sillares y trazó con un compás de las bóvedas en marzo de $1403^{105}$.

La operación podía ser intuitiva y práctica o revestirse de la espectacularidad de una performance como la que se representó en Bítem, cerca de Tortosa, el 14 de agosto de 1346 y al comenzar las obras del campanario de la Catedral de Valencia en 1381. A Bernat Dalguaire se le ordenó que hiciera la traza "en lugar donde pudiese ser bien visto" y estuvo ocupado en Bítem, donde existía una residencia episcopal, siete días con la ayuda de otros tres canteros; una vez terminada, se trasladaron hasta allí el obispo y algunos canónigos para verla ${ }^{106}$. Andreu Julià, que llevaba un lustro al frente de las obras de la seo tortosina, apreció la fuerza de la escenificación para convencer a los promotores y poner en marcha inmediatamente las obras del campanario luego conocido como Micalet en abril de 1381, teniendo quizá también en cuenta el dibujo que había trazado él mismo del campanario de la Catedral de Lérida en $1377^{107}$. En esta ocasión la función tuvo lugar en unas eras de Ruzafa, en las afueras de Valencia y sirvió para trazar los cimientos durante seis días ${ }^{108}$. La duración de estas operaciones y la necesidad de un espacio despejado para desarrollarlas sugieren un sistema de trazado a escala 1:1 que permitía, acaso, deducir el alzado de la planta.

${ }^{103}$ A. ZARAGOZÁ y M. GÓMEZ-FERRER, op. cit., 2007, pp. 220-224.

${ }^{104}$ AMV, Sotsobreria de Murs i Valls, d33-13, ff. 139v-140v, "per fer una mostra del pont del portal dels Cathalans (...) per rahó de despeses e messions que ha fetes, de paper e amidó e aygua cuyta, en fer una mostra de paper quels honrats jurats li han feta fer per rahó del pont dels Cathalans, que volen fer de nou". Citado por M.M. CÁRCEL ORTÍ, "Vida y urbanismo en la Valencia del siglo XV", Miscel.lània de Textos Medievals, 6 (1992), pp. 310-311. La cantidad de yeso empleada (un cahiz valenciano equivale a 201 litros) induce a pensar que se trataba en este caso de un modelo a escala 1:1 para los arcos del puente y no de una maqueta, véase A. ZARAGOZA CATALÁN y A. GARCÍA CODOÑER, op. cit., 1993, pp. 43-44.

${ }^{105}$ La noticia del empleo de estos recursos técnicos, habituales en la práctica constructiva de época gótica, se deduce de la compra de una hoja de madera "per a fer mol.les a les pedres de les voltes del pont de la Trinitat y dos quartons de fusta de XXXII palms de larch per al compàs de les voltes del dit pont". AMV, SMV, d3-15, f. 158r. Alusiones contemporáneas en la documentación valenciana al uso del compás para la traza de arcos y bóvedas han sido analizadas por M. GÓMEZ-FERRER LOZANO, op. cit., 1997-1998, pp. 97-98. El proceso constructivo del puente fue resumido en A. SERRA DESFILIS, op. cit., 2002, pp. 118-124.

106 V. ALMUNI BALADA, op. cit., 2007, vol. I, pp. 72-73.

${ }^{107}$ Ibidem, p. 105.

${ }^{108}$ J. SANCHIS SIVERA, op. cit., 1909, pp. 90-101, particularmente, p. 95, nota 5. 
Pocas prácticas de la transmisión del conocimiento arquitectónico en la Valencia medieval se apartan de las conocidas en otros estados de la Corona de Aragón y en el resto de Europa. La movilidad de los maestros, la enseñanza en el seno del taller, los intentos reguladores de las corporaciones y la traza como expresión del ingenio magistral no difieren mucho de cuanto sabemos de otros territorios. La riqueza de las fuentes valencianas es notable, pero no tanto como para permitirnos indagar en los aspectos más intrigantes. De la alfabetización del artesanado y en particular de los maestros de obras sabemos todavía muy poco y por tanto sólo podemos especular sobre las consecuencias que tuviera en la formación de jóvenes y adultos. El contenido exacto de las enseñanzas técnicas, apenas regladas, se nos escaparía si no fuera por las fugaces alusiones al arte de la geometría, la razón del compás o, de manera aún más vaga, al buen oficio de los maestros expertos. La experiencia parece haberse tenido por una cualificación estimable, revalidada cuando se daba muestra de ingenio y aptitud para dar una solución original a un problema práctico. Se advierte, con todo, una actitud de aprecio y reconocimiento por el saber acumulado en los peritos y, en especial, por las posibilidades de aplicarlo a los designios de gobernantes y poderosos. Los vestigios materiales de la transferencia del saber práctico más apreciables hoy son las propias obras, con sus alardes en la estereotomía, el ornato y la representación de los valores religiosos, políticos y culturales en la arquitectura de aquel tiempo; las huellas en la documentación se antojan fragmentarias y dispersas, pero suficientes al fin para registrar un vivaz intercambio de modelos, la solvencia del sistema de aprendizaje y las inquietudes de los maestros, con frecuencia viajeros e innovadores. 